NBER WORKING PAPER SERIES

\title{
THE HEALTH CARE CONSEQUENCES OF SMOKING AND ITS REGULATION
}

\author{
Michael J. Moore \\ James W. Hughes \\ Working Paper 7979 \\ http://www.nber.org/papers/w7979 \\ NATIONAL BUREAU OF ECONOMIC RESEARCH \\ 1050 Massachusetts Avenue \\ Cambridge, MA 02138 \\ October 2000
}

We are grateful to Alan Garber, Michael Grossman, Willard Manning, John Mullahy, Sam Peltzman, Tom Philipson, Jim Rebitzer, and Richard Thaler, and to seminar participants at Boston University, CUNY/NBER, Dartmouth, RAND, Stanford, Wisconsin and Chicago for comments. All remaining errors are our own. MJM would like to thank the John M. Olin Foundation, which provided research support as the Olin Visiting Associate Professor, Stigler Center for the Study of the Economy and the State, University of Chicago. The views expressed herein are those of the authors, and not necessarily those of the Olin Foundation, the National Bureau of Economic Research, nor of any other organization.

(C) 2000 by Michael J. Moore and James W. Hughes. All rights reserved. Short sections of text, not to exceed two paragraphs, may be quoted without explicit permission provided that full credit, including (C) notice, is given to the source. 
The Health Care Consequences of Smoking and its Regulation

Michael J. Moore and James W. Hughes

NBER Working Paper No. 7979

October 2000

JEL No. 118

\begin{abstract}
The literature on the health economics of smoking presents two principal facts: that smoking increases health care costs, and that restrictions on smoking lead to reductions in smoking prevalence and intensity. Some researchers have hypothesized that these two facts, in combination, allow the inference that restricting smoking will lower health care costs. For a variety of reasons, however, observed associations between smoking and health care use on the one hand, and regulations and smoking on the other, do not imply a casual effect of the restrictions on health care.

This paper extends the literature by examining whether cigarette tax increases lead to lower health care costs. Using data from the 1991 and 1993 National Heath Interview Surveys, it first reproduces the principal results in the literature on smoking, taxes, and health care utilization, and then estimates the effects of tobacco taxes on health care. The results indicate that once one controls for endogenous quits, the health care benefits of smoking cessation are greater than previously believed. There is weak evidence that tax increases lead to higher cessation rates. In combination, these results suggest that, in addition providing a source for funding excess health care costs, tax increases may lower health care costs (for given longevity) directly by inducing smokers to quit.
\end{abstract}

\author{
Michael J. Moore \\ Faculty 121 \\ Darden School of Business Administration \\ University of Virginia \\ Charlottsville, VA 22906 \\ mooremi@darden.virginia.edu \\ and NBER
}

James W. Hughes

Department of Economics

Bates College

Lewiston, ME 04240

jhughes@bates.edu 


\section{Introduction}

Three results dominate the health economics literature on the causes and consequences of smoking: (1) increased excise taxes and other restrictions reduce smoking; (2) increases in smoking lead to a deterioration in health; (3) this deterioration in health leads to higher health care costs. One of the most notable recent health policy events, the multi-billion dollar settlement between state attorneys general and the major tobacco companies, is a direct consequence of these higher health care costs.

The liability settlement is only the most recent attempt by government to intervene in the market for smoking. Governments have implemented information policies, such as the 1956 report by the British Health Service, and the 1964 U.S. Surgeon General's Report on the link between smoking and lung cancer, as well as the 1970 broadcast advertising ban. Tax policy has been a frequent tool in government attempts to limit smoking. Policies have also tried to limit smoking more directly through smoking bans in state and federal buildings, in addition to bans in certain private establishments.

Such government restrictions stem from two motivations. First, as a revenuegenerating device, tobacco excise taxes can be particularly effective, as smoking demand is relatively inelastic. Tobacco tax revenues, at least ostensibly, can then be targeted to finance the greater health care costs due to smoking. Second, some of the effects of smoking are external. The most obvious of these are the excess health insurance premiums paid by nonsmokers. Less obvious are the effects due to the decreased longevity of smokers. Tax revenues are lost due to premature mortality that would otherwise help fund public programs. These losses are offset by reduced withdrawals 
from public programs. More controversial are the potential external costs to the unborn, and the health costs of passive smoking at home and in public places.

Interest in understanding the costs of smoking should extend beyond these concerns. As a health policy tool, taxes and other restrictions should viewed by public officials as not only a revenue-generating device, but also as deterrent. Higher taxes can deter youths from starting to smoke and encourage current smokers to quit or reduce their cigarette consumption. Proper quantification of these effects is also important, lest overstatement of the costs leads to policies that unduly penalize smokers.

Smoking costs are of interest to a broader constituency than just government policymakers. Employers, insurance providers, regulators, smokers, and nonsmokers of all ages are potentially affected by smoking, and thus by regulatory interventions aimed at altering smoking practices. A full balancing of the costs and benefits of tobacco regulatory interventions requires recognition of these many facets, and sound estimates of their magnitudes. It is these magnitudes, and their interpretation, that provide the focus for this paper.

One particular question that arises from the smoking literature is: If government regulations decrease smoking, will the economic costs of smoking decline? Some analysts have combined estimates of the effects of regulations on smoking, and of the effects of smoking on health care costs to conclude that smoking regulations do reduce the economic cost of smoking. Such an inference is, however, premature at least. For a variety of reasons that we explain below, observed associations between regulation and smoking, on the one hand, and smoking and its economic costs on the other, do not imply that more stringent regulation will lead to lower costs. 
In this study, we provide the first direct estimates of the effects of smoking regulations, in particular cigarette excise taxes, on the economic costs of smoking. The outcomes studied here include hospitalizations and their duration, physician visits, and lost worktime. The issues that we address are more generally relevant to other aspects of the smoking-health-cost nexus as well, and we offer comments on these aspects of the problem in what follows.

The implications of these issues, and of the results described below, are substantial. Earlier studies (see Harris (1987), and Warner (1986)) have inferred a direct effect of regulations on health care costs from disparate studies, rather than estimating it directly in a single dataset. Such a procedure potentially misstates the net benefits of any intervention. Interpreting the observed associations between regulations and smoking and between smoking and health care as causal, when in fact they might reflect other underlying mechanisms, will lead to mistaken inferences. Making health and regulatory policy on the basis of such inferences will do more economic harm than good.

\section{Literature Review}

\section{Smoking, Health, and Health Care Costs}

Considerable empirical evidence documents the effects of smoking on health. The Surgeon General's Reports on the Health Consequences of Smoking (USDHHS, various years), for example, provide compelling evidence that smoking increases mortality due to heart disease, cancer, and chronic obstructive pulmonary diseases. Mortality increases with quantity smoked and the length of smoking career. It increases with tar and nicotine levels, and interacts positively with alcohol consumption. It decreases following cessation or reductions in quantity smoked, particularly among healthy quitters. 
Smoking exhibits similar effects on morbidity. One highly influential study, by economist Willard Manning and his colleagues (Manning, et al., 1993) concludes that smoking (and also excess alcohol consumption and sedentary lifestyle) increases excess, or external, health care costs dramatically. Despite this, the Manning study concluded that the cigarette excise taxes were at about the proper level, at least from the perspective of social welfare maximization. Manning also concluded that alcohol taxes were quite low relative to their socially optimal level. Perhaps the most surprising finding in the Manning study is that the excess health care costs of smoking paid by nonsmokers are almost exactly offset by a transfer of wealth from smokers to nonsmokers. This transfer is comprised of the pension benefits of smokers that go uncollected due to smokers' reduced longevity. ${ }^{1}$

Smoking taxes, and other restrictions

A similarly extensive literature documents the effects of price and/or tax increases on tobacco consumption. ${ }^{2}$ This literature clearly indicates that tobacco consumption responds inelastically to price increases. Grossman (1989) observes that much of the reduction in aggregate smoking results from quits. A 5 percent reduction in total smoking by pack-a-day smokers implies, at one extreme, a reduction in smoking of 1 cigarette per person per day. It is also consistent, however, with 5 out of every 100 packa-day smokers quitting entirely, while the remaining 95 are unaffected. The latter response is more likely to result in measurable health effects, as small reductions in smoking by large numbers of smokers are unlikely to have a significant effect on health outcomes. On the other hand, quits by otherwise healthy smokers lead to immediate

\footnotetext{
${ }^{1}$ See also Viscusi (1994).
} 
improvements in smoking-related mortality. The stylized fact in the literature, at this point, is that roughly half of the reduction in smoking due to price and tax increases is due to quits, and the remainder is due to reduced smoking by current smokers.

A second broad conclusion from the literature is that the effects of higher prices and taxes are much stronger among younger people, both in terms of smoking prevalence as well as smoking intensity. As about $90 \%$ of people decide whether to ever smoke by age 25 , the participation effects of interventions on smoking initiation are felt almost exclusively among young people.

\section{Regulations and Health}

Evidence on the relationship between regulatory interventions and health outcomes is mixed. Cook and Tauchen (1982) and Moore (1996) find statistically significant reductions in chronic effects of alcohol and tobacco consumption in reduced form estimates of tax-mortality regressions. Evans and Ringel (1998) find that tobacco tax increases lead to a small, but statistically significant, increase in birthweight.

On the other hand, considerable evidence indicates that regulations can lead to unexpected, and sometimes adverse, health outcomes. Some of the most notable results include Viscusi's (1984) finding that protective safety cap regulations lead to more accidental poisonings, and Peltzman's (1975) finding that automobile safety regulations lead to increases in certain types of accidents. ${ }^{3}$ On the issue of smoking, Evans and Farrelly (1998) document a statistically significant substitution towards higher tar content in cigarettes as taxes increase.

\footnotetext{
${ }^{2}$ Smoking studies are summarized in Chaloupka and Warner (2000), Manning, et al. (1993), and Viscusi (1992).

${ }^{3}$ See, however, Harris (1996) on the mortality effects of safety caps.
} 
The effect of smoking regulations on health care utilization and other outcomes depends crucially on individuals' response to the changed incentives. Substitutions towards more dangerous substances (other drugs, stronger cigarettes) would reduce the regulation's impact. If demand for smoking is most inelastic among those most at risk for disease, regulatory interventions may yield little observable response in health care utilization. The trend towards certain smoke-free or smoke-friendly environments may have little effect other than sorting and self-selection by workers and customers.

Estimation of the causal effect of regulations presents related problems. Unobservables such as differences in the rate of time preference among individuals, and unobserved health shocks that result in reverse causation between smoking and health care utilization, confound the empirical analysis of smoking and health care. Sorting in the labor and health care markets, and mismatches between affected populations in empirical models of smoking and regulation, and of health care and smoking, can also present difficulties for the empirical estimation. Estimates of the effect of regulations on smoking are also confounded by regulatory variables that are correlated with both the intervention and with smoking. In assessing the effects of, for example, an excise tax increase, other state-level interventions, such as bans on smoking in public places, or information campaigns, must be controlled for in order to identify the tax effect. Likewise, environmental factors, including the local culture, age composition, the importance of smoking to the local economy, and the local unemployment rate, might be correlated with both individual cigarette consumption and with the stringency of regulations. Finally, in assessing the effects of firm-level policies such as workplace smoking bans, account must be taken of factors such as firm-wide smoking prevalence, 
and other firm policies that might affect both smoking behavior and the prevalence of smoking bans.

The remainder of the paper seeks to provide some perspective on these issues. The next section discusses the economic issues in more detail. Following that, the data used in this study and the empirical results are presented. The final section of the paper discusses limitations of the current study and suggests future directions.

\section{Conceptual and Empirical Framework}

The principal finding that we seek to examine is not controversial: regulations that limit smoking are associated with a decreased demand for health care, and with changes in other smoking-related health and labor market outcomes. The focus of our analysis is on the both the magnitude and the interpretation of the effect. In particular, we seek to determine the change in health care utilization generated by exogenous changes in smoking, and the change in smoking generated by exogenous interventions.

To fix our ideas, imagine there is an exogenous shock, such as a tax increase motivated by revenue concerns. In response to this shock, some smokers might continue to smoke but reduce their tobacco intake, while others might quit entirely. In each of these instances, evidence indicates a significant lowering of health care costs. The observed association between smoking changes and changes in health care utilization here would estimate the causal effect of smoking cessation on health care costs.

Imagine now the opposite extreme of an completely endogenous shock, such as a heart attack or a diagnosis of smoking-related illness, such as high blood pressure or emphysema. Here, we would expect to see a reduction in smoking due to the adverse health event, and a corresponding increase in health care utilization. In this case, 
obviously, the causality runs in the other direction, and the observed association between smoking and health care use does not reflect the causal influence of smoking cessation. Failure to control for this reverse causation in general will lead to an understatement of the effects of smoking cessation on health care costs.

A controlled experiment designed to test the hypothesis that smoking leads to increased health care costs could proceed in the following manner. Individual subjects would be selected at random and their health care and labor market practices observed. Measurements taken would include health care variables such as smoking, physician visits, and hospitalizations. Labor market outcomes such as lost workdays, health insurance costs to employers, labor force participation, and hours of work would also be observed. Following these baseline observations, randomly selected individuals would be assigned to smoking/nonsmoking treatment groups. After stabilization of their respective smoking patterns, and given enough time for smoking to exert an effect on health care use, the same health care and labor market practices would be measured postintervention for each group. Differences in health care use in the treatment group relative to the changes in health care use among nonsmoking controls would indicate a causal effect of smoking on the outcomes of interest.

To estimate the effects of regulations on health care, we could then hypothetically take the treatment group in the preceding experiment, and assign a randomly selected portion to a more stringent regulatory environment, such as hazard information provision, bans on smoking at their places of work, or a tax on their tobacco consumption. Once again, changes in the patterns of health care use, smoking, and labor market performance 
in the treatment group, now relative to the smoking controls, would indicate causal effects of the regulations on the outcomes of interest.

Such an experiment is obviously not possible, for both ethical and economic reasons. The primary means for evaluating questions such as we pose here, rather, utilize nonexperimental data, and attempt to control for the many confounding influences noted above in a variety of ways. Observed nonexperimental data represent a rather murky stew of both exogenous and endogenous smoking, regulation, and health care processes. Our task here is to separate out the effects of the competing influences on both smoking and on health care use.

To introduce the economic and statistical issues, denote the expectation of health care expenditures by $\mathrm{E}[\mathrm{HC}]$, and partition it into expenditures by never smokers, $\mathrm{N}$, former smokers, F, and current smokers, $\mathrm{C}$, weighted by their respective probabilities of occurrence. Expected health care use is then equal to

$$
E[H C]=P(N) E[H C \mid N]+P(F) E[H C \mid F]+P(C) E[H C \mid C] .
$$

Since the probabilities sum to one, we can rewrite this as

$$
E[H C]=P(N) E[H C \mid N]+P(F) E[H C \mid F]+(1-P(N)-P(F)) E[H C \mid C] .
$$

Differentiation of equation (2) yields an expression that partitions changes in health care into two components: those due to changes in the expected utilizations, conditional on smoking status, and those due to changes in smoking status, conditional on utilization. Since regulations will probably not affect the conditional expectations of health care expenditures, we ignore these former effects, and focus our attention on the effects of changes in smoking status. Letting $\Delta$ indicate change, we can write changes in health care due to changes in smoking status as 


$$
\Delta E[H C]=[E[H C \mid N]-E[H C \mid C]] \Delta P(N)+[E[H C \mid F]-E[H C \mid C]] \Delta P(F) .
$$

Thus, changes in health care expenditures due to changes in smoking status equal the sum of the relative costs of never and former smoking, weighted by the changes in the probabilities of never and former smoking status. Clearly, if the costs of never and/or former smoking are lower than current, anything that increases the likelihood of either, relative to current smoking, will decrease health care costs.

Regulations, $\mathrm{R}$, will affect health care costs via their effects on smoking status. If we denote a regulatory intervention by $\Delta \mathrm{R}$, then the effect on health care is given by the expression

$$
\begin{aligned}
\Delta E[H C] / \Delta R=[[E[H C \mid N]-E[H C \mid C]](\Delta P(N) / \Delta R) \\
+[E[H C \mid F]-E[H C \mid C]](\Delta P(F) / \Delta R) .
\end{aligned}
$$

In this framework, changes in health care costs due to regulatory interventions operate entirely through the effects of the regulations on smoking status. Estimation of the regulatory effect thus requires two pieces of information: the relative health care cost differentials, and the effects of the intervention on smoking status. If estimates of either or both of these components are biased, then mistaken inferences about the regulatory effect are the likely result.

The most well-known estimates of the cost differentials are found in Manning, et al., (1993). We replicate these estimates below using more recent data from the National Health Interview Surveys, and illustrate their use in constructing estimates of health care costs. We also illustrate how the classification of former smokers affects these calculations. 
Estimates of the effects of regulatory interventions on smoking participation are extensive. ${ }^{4}$ Interventions studied include excise taxes, information policies, and bans on smoking in public places. ${ }^{5}$ We also present estimates below that replicate the main findings in this literature, to position ourselves for the subsequent analyses.

Broadly speaking, the findings in this literature are twofold: (1) smoking leads to higher health care costs, and; (2) regulations that raise the cost of smoking reduce smoking. Simply combining these two facts to compute an ad hoc estimate of the effects of the intervention on health care costs may not be valid for a variety of reasons. ${ }^{6}$ First, as noted above, the estimated cost differentials are potentially confounded by the endogenous nature of smoking. ${ }^{7}$ The second source of bias in the policy experiment arises from mistaken inferences about the effects of the intervention on smoking status. Tax increases might lead to substitutions towards higher tar content generic cigarettes, with a reduction in number of cigarettes smoked, which would tend to increase health problems. ${ }^{8}$ Workplace smoking bans might lead smokers to congregate in poorly ventilated smoking areas, or to smoke cigarettes more intensely both at work and at home, thus inhaling the higher concentrations of chemicals as the cigarette burns nearer to the filter. Alternatively, the regulatory stringency could reflect political economy effects, such as a higher ex ante prevalence of nonsmokers where smoking is banned, that are also related to individual smoking through peer group and social interaction effects. ${ }^{9}$ Low taxes could also be correlated with other omitted regulations, and also with aspects

\footnotetext{
${ }_{5}^{4}$ See Chaloupka and Warner (2000) for an extensive review.

${ }^{5}$ For tax effects, see the work of Grossman and his colleagues (Grossman, et al., (1993)); for information policies, see Schneider, Klein, and Murphy (1981); for laws restricting indoor smoking, see Chaloupka (1994) and Jacobson and Wasserman (1997).

${ }^{6}$ See, for example, Warner (1986) and Harris (1987).

${ }^{7}$ See Moore (1996) and Tollison and Wagner (1992).

${ }^{8}$ See Viscusi (1994).
} 
of the local environment, such as culture and labor market conditions. If these local characteristics also affect individual smoking, estimated tax elasticities that fail to take them into account are biased.

A third source of bias, which can arise even if the cost differentials and smoking participation effects are consistently estimated, results from a mismatch of effects, where those smokers who respond to the regulation are not the same smokers whose behavior is causing health problems. If an excise tax increase or a workplace smoking ban lead to a reduction in smoking primarily among light smokers, but heavy smokers are the ones with higher health care costs, then the tax will have no effect on health care. In this case, we could actually have consistent estimates of both effects, but the inference reached by combining the effects would be invalid. ${ }^{10}$

This problem arises due to a failure to incorporate the covariance of the coefficients into the exercise. The ad hoc policy experiment simply multiplies estimates of the coefficients from separate regressions. This is not correct, however, since, for a tax-smoking coefficient $\delta$, and a smoking-health coefficient $\gamma$, the following is approximately true:

$$
E[\hat{\delta} \hat{\gamma}]=E[\hat{\delta}] E[\hat{\gamma}]+\operatorname{Cov}(\hat{\delta} \hat{\gamma})
$$

Thus, the product of estimated coefficients will over or understate the true effect according to the sign of the covariance.

We address these problems in two distinct ways. First, to estimate the effects of regulations on smoking cessation, $(\Delta P(F) / \Delta R)$, and of cessation on health care costs, $E[H C \mid F]-E[H C \mid C]$, we partition the former smokers in our 1991 NHIS sample into

\footnotetext{
${ }^{9}$ See Moore, (2000).
} 
recent and long-term quitters, and compare their health care costs to those of current smokers. Recent quitters will include a larger fraction of endogenous quitters, or perhaps more accurately will exhibit health care use patterns that are more likely to reflect the effects of past smoking on health. Long term quitters will include only those whose health care use has stabilized at a level more reflective of their no longer smoking. This partitioning will capture two influences we seek to measure: that of smoking cessation independent of unobserved health shocks, and also the latency period between smoking cessation and the return to good health. When combined with estimates of the effects of regulations on quitting, these results provide information on the causal effect of the regulations on lifetime health care as they operate through smoking cessation.

Estimates of the effects of regulations on youth smoking, and of youth smoking on health care use, are not emphasized in our analysis, although we will comment on their role. Most of the health care implications for youthful smokers are long term in nature, and our study focuses more on the short term costs of morbidity considered by Manning, et al. However, our results can be used to help construct lifetime profiles of health care usage and we provide some examples below.

Our second empirical approach estimates the reduced form of the model. While leaving the structural mechanisms by which regulations operate unspecified, reduced form estimates provide direct evidence on the question of whether smoking regulations affect health care costs. This approach circumvents many of the problems described above, by relegating the structural effects to "black box" status. In particular, bias in estimates of the cost differentials, and also the mismatch problem, will not plague the

\footnotetext{
${ }^{10}$ See Moore and Hughes (2000).
} 
reduced form estimates. On the other hand, the potential biases in estimates of the regulatory effects due to omitted factors, such as other regulations, will remain.

\section{Empirical Results}

\section{Aggregate Data}

To illustrate some of the issues described above, we first examine data aggregated by state and year. Figure 1 describes the broad trends in per capita smoking and in the real tax rate for the period 1960-95. Each series is indexed to 1.0 for 1983 . Smoking, which had risen steadily from 1945-60, was relatively flat from 1960 until it began a steady decline around 1980. Taxes likewise were relatively stable, until the inflation of 1970-80 eroded them significantly in real terms. The 1983 tax increase led to an increase in overall tax rates which has persisted, and increased by about another 10 percent, with further Federal and state tax increases. While it is tempting to relate the recent decline in smoking to the tax increases, the experience in the 1970s indicates that there is more to the story.

Table 1 describes the aggregate data. A panel of state-level data for the years 195488 was constructed for purposes of the aggregate analysis. Three models are estimated: a smoking-mortality model that corresponds to a health production function, a cigarette demand model, and a reduced form tax-mortality model. Total and smoking-related mortality rates are used as dependent variables in the mortality regressions. Control variables include per capita income, two age mix variables, and state and year dummy variables.

As Table 1 illustrates, average per capita consumption of cigarettes equals about 120 packs per year. Given smoking participation of about 30 percent on average over the 
sample period, this implies about one pack per day smoked by smokers. Nominal prices and excise tax rates vary widely across states. ${ }^{11}$ As a rule, real prices and tax rates declined over the sample period, although there were some periods of increase, such as that due to the Federal tax increase in 1983. Mortality in the smoking-related disease categories is substantial, due to the fact that cardiovascular mortality represents such a large portion of overall mortality. Note that actual smoking related mortality is a fraction of total mortality in the smoking related categories. Relative risk for heart disease in smokers, for example, is about $3: 1$. With $30 \%$ of the population smoking and cardiovascular mortality of about 400 deaths per 100,000 population, this would imply about 750 deaths per 100,000 for CVD among smokers, and 250 among nonsmokers.

Table 2a presents estimates of the smoking and income coefficients from the structural versions of the health production model. In the OLS estimates, mortality is regressed on per capita smoking and the control variables. The time dummies control for economy-wide effects such as underlying health trends, the issuance of the 1963 Surgeon Generals Report that first officially linked smoking and cancer, the activity surrounding broadcast advertising in the late 60s and early 70s, and the Federal tax increase of 1983. The state dummies control for time-invariant state-specific effects that might be correlated with both tax rates and mortality. In the two-stage least squares (2SLS) estimates, smoking is treated as endogenous, and the excise tax rate is used as the identifying instrumental variable.

The OLS estimates in column 1 imply that an increase in aggregate smoking of two packs per capita per year will increase mortality in the short run by almost 1 death per

\footnotetext{
${ }^{11}$ Nominal values are deflated for purposes of the regression estimation using the overall consumer price index.
} 
100,000 , or about 2,500 deaths nationally. If all of this aggregate increase were due to greater smoking participation at a level of one pack per day, an aggregate increase of two packs per year would be generated by 50 additional smokers per 100,000 population.

It was argued above that reverse causation is an important issue in estimating the effects of smoking on health and health care use when using nonexperimental data, and that failure to control for this can lead to an understatement of the estimated health effects. We can control for this reverse causation by estimating the production model using two stage least squares. The two stage estimates indicate that the nonrandom nature of smoking leads to an substantial understatement of its effect on mortality. According to the 2SLS results, the 2 pack/day increase in aggregate smoking described above will increase the mortality rate by 1.6 per year or 4000 deaths nationally. ${ }^{12}$

Table $2 \mathrm{~b}$ presents estimates of cigarette demand equations, and of mortality-tax models similar to those estimated by Cook and Tauchen (1982) and Moore (1996). As Table $2 b$ indicates, tax changes lead to significant declines in aggregate smoking. The estimated tax-smoking elasticity equals about -0.4 at the sample means, which is consistent with the majority of evidence reported in the literature (See Chaloupka and Warner (2000)). If we were to perform the policy experiment described above using these estimates and those in Table 2a, we would conclude that the tax-mortality effect is the product of the tax-smoking and smoking-mortality coefficients, or about $.5(1.266 \mathrm{x}$ .387). These are about $1 / 3$ smaller than the two stage estimates, which control for the endogeneity of smoking.

\footnotetext{
${ }^{12}$ It should be emphasized that these represent short-run effects only. Estimates of a production relationship with stock effects, although interesting in their own right, are unnecessary for purposes of this example, which is meant only to illustrate the potential consequences of treating smoking as exogenous in a health production function.
} 
We can also estimate the mortality effects of taxes directly via the reduced form of the model, i.e., by eliminating the smoking variable and regressing mortality directly on the tax rate. In Table $2 \mathrm{~b}$, these results indicate that tax increases lead to significant shortrun declines in overall mortality in the reduced form. ${ }^{13}$ According to the estimates for total mortality, a $10 \%$ increase in the tobacco excise tax will lead to slightly less than $1 / 2$ of $1 \%$ reduction in overall mortality.

The results in Table $2 \mathrm{~b}$ present some evidence on the validity of the instrumental variables estimates. The cigarette tax is a powerful omitted variable with which to estimate the smoking effect in the structural model. Whether it meets the more subtle requirements of admissibility as an instrument is a more difficult question. Angrist, et al. (1996) provide a useful perspective by which to evaluate this question. For smoking to be interpreted as an experimental treatment in the two stage least squares estimates in Table 2a, it must be the case that the effect of taxes on health operates entirely through the smoking variable. Thus, if taxes are correlated with the unobservable variables that are also related to health, their validity as an instrument is questionable. To a certain extent, this can be controlled for by including a rich set of control variables. In the aggregate results here, the state and time dummies, income, and age mix are all significant predictors of the health outcome. Given the inclusion of these other variables as regressors, the tax variable is to be interpreted as explaining variation in smoking using within-state changes in taxes, over time. If there are no other important time- and state-varying factors that affect smoking and health, the two stage estimates can be interpreted as causal. Two possible candidates not considered here are border taxes and

\footnotetext{
${ }^{13}$ See Moore (1996) for a discussion of this result, and a decomposition of the result into more detailed mortality categories.
} 
other smoking and health related regulations that may be changing at the state level. Most evidence indicates that border taxes are significant determinants of smoking. However, their inclusion as regressors does not appear to affect estimated effects of ownstate tax changes on smoking or on health outcomes in other studies. Similar conclusions hold for state-level smoking regulations. ${ }^{14}$

As a final note, cigarette taxes have been used primarily as a revenue generating device, so we would not expect them to be related directly to mortality rates. Moore (1996) provides statistical evidence that the tax rate is not directly related to the health variables, but rather operates through the smoking variable. ${ }^{15}$

Recall that the two principal facts to be examined have to do with the effects of smoking on health care, and of regulations on smoking. The aggregate regression results indicate that reverse causation may plague estimates of smoking-mortality models. The results in Tables 3-5 further confirm this suspicion.

\section{Epidemiological Evidence}

Table 3 presents evidence on the relationship between smoking status and cardiovascular mortality for current and former smokers from USDHHS (1990). Results for large-scale epidemiological studies are presented that compare mortality ratios for current and former smokers, with and without controls for preexisting health conditions. In the Hammond and Horn studies, for example, the effects of endogenous quitting are readily apparent. Among smokers of less than one pack per day, CHD mortality is higher among recent quitters than current smokers. Among heavier smokers, the excess

\footnotetext{
${ }^{14}$ See Evans and Ringel (1998).

${ }^{15}$ In the period covered by this data, there is one recorded instance of a tax increase explicitly targeted towards health improvement. This occurred in New Hampshire in 1984.
} 
mortality among recent quitters is even more substantial. It is interesting to note that, in this study, former smokers eventually return to CHD mortality rates (after 10 years) that are practically indistinguishable from those of never smokers. In Hammond and Garfinkel (1969), where only men free of diagnosed CHD are included, we see an immediate decline in mortality following quits. Likewise, in the ACS 50-state study of 1.2 million males and females, the mortality ratios for light smoking healthy males drop by about one-third almost immediately after quitting, while mortality for all male smokers (not shown), including those with health problems, is $50-100 \%$ higher than for current smokers, depending on amount smoked. Mortality ratios for females exhibit identical patterns for five years following quitting.

Table 4 presents similar evidence for lung cancer mortality. Two results in Table 4 are particularly striking. First, we once again see the effects of endogenous quitting, as lung cancer mortality rates for recent quitters are consistently higher, often dramatically so, than for current smokers. Also, despite the long latency period for lung cancers, it is interesting to note that lung cancer mortality rates begin to fall below those of current smokers only 3-5 years after quitting. In some cases, the decline is substantial.

Table 5 presents similar results for oral cancers. Once again, we see that mortality rates for recent quitters are higher than for current smokers, unless smokers who quit on their doctors orders are excluded. The consistent implication in these tables is that health is a fundamental determinant of smoking status. As such, it is incorrect to interpret observed associations between smoking and health as causal, without further controls (such as excluding unhealthy quitters in the epidemiological studies). 
The implications of these results for the welfare estimates should be clear. Epidemiological estimates of the effects of smoking on mortality and longevity in human subjects are typically not based on random assignment to smoking levels. When we control for this nonrandom assignment, continued smoking increases mortality, and therefore reduces longevity, by more than previously believed. One implication is that, since reduced longevity results in a transfer of pension wealth that compensates nonsmokers for the excess health care costs of smokers, the amount of this transfer is understated, and the external costs of smoking are overstated, when smoking is treated as exogenously determined.

\section{Manning et al. Replication}

In this section we introduce the microdata used for the remainder of the study, and present a replication of the results of Manning et al. (1993). Table 6 defines the variables, which are drawn from the 1991 and 1993 National Health Interview Surveys. Table 7 presents descriptive results by smoking status. Comparison of the means across the three columns in Table 7 provides suggestive, but far from conclusive, evidence on many of the relationships of interest to this study. Current smokers spend more days in the hospital than never smokers, with little difference in hospitalization rate. This suggests that current smokers health problems are more severe than those of nonsmokers, as their average length of stay is greater. Former smokers exhibit even greater use of the hospital than current smokers, suggestive again of a causal effect running from health to smoking status. Current and former smokers miss 30-50\% more workdays than nonsmokers. On the other hand, current and never smokers have approximately the same rate of utilization of outpatient doctor visits, while former smokers use substantially 
more. Since this measure includes "well care" episodes like annual checkups, this is not particularly surprising. Also, visits to the doctor may provide an impetus to quit smoking, again suggesting a causal relationship from health care to smoking status.

Personal demographic characteristics do not differ appreciably across smoking categories. Significant differences are observed for education, where never and former smokers are more than twice as likely to have finished college, and only $1 / 4$ less likely to have dropped out of high school. Likewise for income, where smokers are much less likely to be in the highest income bracket of $\$ 50,000$ a year or more. Never smokers are more likely to be single than are current smokers, while current smokers are twice as likely to be divorced or separated. Former smokers are more likely to be married than are current and never, and less likely to be single. The three groups do not differ on average body mass or family size. There is a slightly larger fraction of never and former smokers working in the public sector.

The next set of estimates examines the self-assessed health and the health practices of the three groups. The majority of sample members in all groups rate their own health as good to excellent. There is a tendency for never smokers to rate their health more highly: $37 \%$ of the never smokers report being in excellent health, compared to $29 \%$ for current, and $32 \%$ for former. Very few sample members report their health as fair or poor, but fair/poor health is more likely among ever smokers.

Seat belt use is often used as a proxy for health attitudes. The more concerned one is about longevity and health, the more likely that person is to use a seat belt. To the extent these attitudes are correlated with smoking status as well, the results in Table 7 suggest that seat belt use is proxying attitudes as it should: roughly $14 \%$ more of the never and 
former smokers always use their seat belts than do the current smokers. Finally, there are interesting differences among the smoking categories in terms of their health insurance coverage. Among those with private insurance, former smokers are about $15 \%$ more likely, and never smokers $10 \%$ more likely, to be covered than are current smokers. This could reflect differences in risk attitudes, or perhaps incentives provided to curtail smoking by insurance policies.

Table 8 provides further details on the characteristics of smokers, former smokers, and never smokers. About $50 \%$ of the sample has never smoked. Males are about $5 \%$ more likely to smoke than females, and blacks are about $4 \%$ less likely to smoke than whites. Older people are more likely to smoke than are younger, as indicated by the declining percentage of never smokers of either gender in older cohorts

Education differences in smoking prevalence are particularly striking. High school dropouts are much less likely to have never smoked, while those who have some schooling beyond high school and/or college are more likely to have never smoked or, if they did smoke at one time, are more likely to have subsequently quit. Much has been written about the connection between schooling and smoking. Does the observed negative correlation reflect a causal influence of education on smoking, where more educated individuals are better able to process health risk information, or does it reflect sorting by rate of time preference, where increased investment in education and aversion to smoking both reflect a greater weight placed on the future? ${ }^{16}$

Table 9 replicates the results of Manning, et al. (1992), using pooled data from the 1991 and 1993 National Health Interview Surveys. As in Manning, et al., we are

\footnotetext{
${ }^{16}$ See Farrel and Fuchs (1982) and Kenkel (1991).
} 
studying four health are outcomes: doctor visits, hospitalizations, days in the hospital, and lost workdays.

We decompose these results on three additional dimensions: estimates are presented in Table 9 for "short form" (i.e., with controls for age, gender, race, and year only), and "long form" models (with additional controls for potentially endogenous variables, such as seat belt use, body mass, insurance coverage, education, etc. that might be correlated with both smoking status and health care use). We also split our sample between workers and non-workers. Finally, Tables 10-13 present estimates of agespecific estimates of the long and short form models.

Our results are quite consistent with those of Manning et al. The health care costs of current and former smoking in Table 9 are significantly higher than those of never smokers. In the case of hospitalizations, the excess is on the order of 25 percent for workers, and $25-55 \%$ for nonworkers. Note that the inclusion of the additional control variables makes a difference only in the nonworker sample, and only for the current smoker effect. Note also that the current and former smoker effects are similar in magnitude.

Hospital days similarly show strong associations between smoking status and utilization. Here, however, nonworking former smokers spend significantly more days in the hospital, while the opposite holds among workers. Doctor visits are typically greater for former smokers than current. This reflects an underlying problem with the doctor visit variable: since many smokers will see the doctor, or quit smoking on doctor's orders, some portion of the observed relationship will reflect causation in the opposite direction. Lost workdays also are significantly higher among smoking workers. In both 
the long and short form models, currents smokers miss work more often than former and never smokers.

There is little evidence in the Table 9 results that inclusion of the additional control variables affects the estimated smoking coefficients. This allays concerns about endogeneity due to omitted variables to some extent. If the included proxies for health attitudes and time preference, such as seat belt use and education, do not alter the estimated smoking effects, it is less likely that residual unobservables will be a problem. However, reverse causation remains a problem, even though the former smoking coefficients in Table 9 are typically lower that the current smoking estimates. In particular, the former smoking coefficients include the health care use of recent quitters with health problems, who are more like current smokers, and the health care use of long term quitters, who are more like never smokers. Separation of these estimates will be taken up below.

This replication presents preliminary evidence on two components of the regulatory effects model given by equation (4). Current smokers have higher health care costs than never smokers, particularly among older cohorts. The health care costs of former smokers appear to be similar in magnitude to those of current smokers based on these preliminary results. These cost differentials can be used to construct estimates of the health care cost differences in (4). However, some of the costs of former smokers might be more correctly attributed to current smoking, if we wish to estimate the long run consequences of smoking cessation, and of regulations that induce smokers to quit. 


\section{Smoking Status Models}

The second set of components of the regulatory effects model are the smoking status-regulation estimates. Table 14 presents estimates of probit models of never and former smoking that provide estimated excise tax effects. The never smoking model is first estimated on the entire pooled 1991/93 NHIS sample. This is obviously misspecified, since the never smoking decision is almost exclusively made before age 25 . However, we present the pooled results as a reference point. The former smoker probit is estimated conditional on ever smoking. ${ }^{17}$

Table 14 presents complete results for pooled long and short form never and former smoking models. In the short form, cigarette taxes have a small, statistically significant effect on never smoking. While suggestive, the fact that this effect is observed over all ages suggests the possibility that the state tax rates are correlated with other variables that affect smoking across all age groups. Males are less likely to have never smoked than are females, and blacks more likely than whites. The pattern of age coefficients is broadly consistent with earlier research: smoking is much more likely among older people.

In the long form, the cigarette tax effect becomes statistically insignificant. This likely reflects the inclusion of the region dummy variables. Other effects of note are those of education, where we see that the less educated are more likely to smoke. Seat belt users are about $10 \%$ less likely to ever smoke, as are individuals with private health insurance coverage. Income effects are largely insignificant. Family composition, on the

\footnotetext{
${ }^{17}$ The sequential structure of the decisions suggests a two-stage probit model with selectivity at the former/current smoking stage. However, identification in the NHIS would be difficult, as there is little information available to identify the never smoking model via exclusion restrictions. Identification off the
} 
other hand, is an important predictor of ever smoking status: each additional family member is associated with a $1.5 \%$ greater likelihood of never smoking, and single people are $5 \%$ less likely to have never smoked than their married counterparts.

Former smokers exhibit similar patterns. The cigarette tax only matters statistically in the short form. Former smokers are more likely in older cohorts. Since males are more likely to smoke, and blacks less likely, it seems reasonable to expect also that males would be more likely to quit, and blacks less likely, conditional on ever smoking. The results in Table 14 support this expectation. The additional control variables exhibit statistically significant positive associations between education and smoking cessation. Likewise, seat belt users are more likely to quit, as are those with private health coverage. Quitters are concentrated in the higher income brackets, and also among the married.

Taken at face value, these coefficient estimates could be used to complete the policy experiment described in equation (4). That is, we could combine estimates of the effects of smoking status on health care use from Table 9 with estimates of the effects of cigarette taxes on smoking status from Table 14 to estimate the effects of taxes on health care. Ideally, we would have age-specific estimated effects. The age-specific smokinghealth care effects could be discounted to present values, combined with the age-specific tax effects, and summed to arrive at an estimate of the lifetime effects of taxes on health care costs. ${ }^{18}$

nonlinearity of the probits is possible, in principle, but requires some untenable assumptions about functional form.

${ }^{18}$ This of course assumes that the cross-cohort effects observed in the data accurately represent the lifecycle costs for any given cohort. It also bears mentioning that an increase in longevity could entail an increase in lifetime health care costs. Reduced smoking should entail a decrease in costs, holding longevity constant, however, and it is this result that we are describing. 
As an example of the kinds of problems that arise in using these estimates to compute regulatory effects, suppose we use the results in Tables 9 and 14 to estimate the effect of a tax increase of $\$ 1 /$ pack on lifetime hospitalizations for nonworkers. The results in Table 9 indicate that the former smokers' hospitalization rates are higher than those of current smokers, particularly in the long form models. Thus, if we combine the short-form tax effects from Table 14, which indicate that a tax increase of $\$ 1 /$ pack would increase quits by 20.7 percentage points, with those in Table 9, which indicate a 34\% higher utilization rate for nonworking former smokers, we would conclude that the tax increase would increase health care costs of hospitalizations by about $7 \%{ }^{19}$

This is clearly not the end of the story. Quitting smoking leads to health improvements that gradually approach those of never smokers. The estimates in Table 9 do not capture this effect, however, since the former smokers will include some recent smokers, many of whom have quit for smoking-related health reasons. Thus, it would be more correct to ascribe some of the observed hospitalizations among former smokers to smoking, with the residual used to compute the health care benefits of smoking cessation.

Tables 10-13 decompose the health care by current and former smoking estimates by age group. The cumulative and long term nature of the health care consequences of smoking are clearly indicated in Tables $10-13$. With few exceptions, no significant relationship between smoking and health care utilization is found until age 36 . There are some significant coefficients among younger workers observed in the short form for hospitalizations, hospital days, and doctor visits, but these are typically dissipated by the inclusion of the long form variables, suggesting that the effects reflect correlated

\footnotetext{
${ }^{19}$ In discussing the effects of a tax increase here and in the remainder of the paper, we will use a figure of $\$ 1 /$ pack in 1983 prices to reflect the normalization of taxes used in the estimates.
} 
behaviors. It is interesting to note that the former smoking estimates are regularly larger than the current smoking effects among older workers. If smoking-related health problems materialize relatively late in life, we would expect recent quitters, in particular, to have higher health care costs. This is borne out in the estimates of Tables 10-13.

Table 15 presents age-specific tax estimates. There is little evidence that taxes affect the never and former smoking decisions of the young in Table 15. The most consistent evidence of any regulatory effect appears in the short form results for the quit equation. The estimates reported there suggest that a $\$ 1$ increase in the tax would have a considerable effect on the quit decision. For the 26-30 year olds, the estimated coefficient is .30 . At the mean tax rate in the data of 33 cents/pack, this implies a quit/tax elasticity of about .67 , which is not unreasonable.

As was the case earlier, we could combine the estimated age-specific smokinghealth care effects presented here with the age-specific tax-smoking estimates in the ad hoc policy experiment. In this case, we could also, in principle, construct an artificial agecosts profile, and estimate the lifetime health care effects of smoking status, and the lifetime benefits of regulations that alter smoking status. The problem of reverse causation once again manifests itself here, however, as can be seen by inspecting the current and former smoking estimates for nonworkers. In particular, since former smokers health care utilization is higher for nonworkers for each of the three outcomes considered, the inference would be that taxes would increase health care costs in this group of smokers, by inducing a shift to the higher cost former smoking status.

What is needed is a way to discriminate between healthy and unhealthy quitters. A simple solution is available in the 1991 NHIS, which provides information on the 
length of time each former smoker has occupied that state. We can thus construct relative health care utilization rates by duration of quit similar to the mortality tables presented earlier.

Our expectation, that long term quitters would have significantly lower costs than current smokers and recent quitters, is strongly borne out by the data. Table 16 presents a decomposition of health costs by smoking status for the 1991 NHIS, with former smokers now grouped into those who quit in the previous year, 1-4 years, 5-9 years, and 10+ years ago. The first four rows of the table present means for the health care outcome variables. Never smokers have consistently lower utilization rates for each outcome. Interestingly, the most recent quitters have substantially higher rates than do the current smokers. After 1 year has elapsed, however, this ranking begins to reverse itself, often quickly and dramatically. The message of these results is that the estimated cost differences in equation (4) must take endogenous quitting into account.

Table 17 presents similar findings, with controls added for the short and long form regression models. In each case, the most recent quitters have higher use rates than do current smokers. This begins to reverse itself almost immediately, to the point that long term quitters health care use patterns are often no different statistically from never smokers. Recent quitters are thus more like current smokers. In estimating the cost differentials for equation (4), it is therefore more accurate to include these costs with those of current smokers. This will serve to increase both the estimated gains of smoking cessation, and those of never smoking, relative to those implied by the earlier replication results. The results in Table 18, for nonworkers, are even more dramatic, although not unexpected. If the recent quitters health care costs reflect health shocks, and the health 
shocks are serious enough to cause the person to leave the labor market, the magnitudes of the recent quit effects should be greater than those for workers.

The final set of results, in Table 19, present estimates of the reduced form. Estimated tax effects by age group are provided there for both short and long form models of each of the four health care outcomes. In the short form results, there are fairly strong, consistent results for hospitalizations of older workers. This result holds up somewhat in the long form, although the estimates are less precise. Given the nature of the exercise, however, where large samples are required to estimate small effects, this is not surprising. Given the inclusion of the region dummies and the other variables in the long form, the estimated tax effects are very difficult to estimate precisely. In the pooled long form results, however, the point estimates indicate a $1 / 2$ of $1 \%$ reduction in the hospitalization rate for a 1 cent increase (in 1983 dollars) in the excise tax rate. At this

rate, the 4 cent/pack tax increases of the early 90 s would result in cost savings of at most $2 \%$, and most likely less, due to the effects of inflation.

\section{Conclusions}

This paper sought to examine the sources of health care savings due to smoking related regulations. While the focus of the empirical analysis was on taxes, any intervention that affects the full price of smoking, such as increases in the ex ante or ex post costs of product liability risk, increased insurance prices, public smoking bans, or increases in expected health costs due to information programs, will have qualitatively similar effects. When account is taken of the endogenous nature of health care costs, the costs of smoking are seen to rise considerably. From the perspective of smoking cessation, failure to control for reverse causation leads to an overstatement of the health 
care costs of former smokers, and a corresponding understatement of the costs of current smoking. In examining the effects of taxes on smoking status, we found mixed evidence. In some specifications, the cigarette tax appears to reduce current smoking on both the initiation and quit margins. However, this result is sensitive to the inclusion of additional control variables. In particular, region effects seem to eliminate much of the state-level effects of taxes. This may reflect the presence of other smoking policies that vary by region, or cultural differences across region that are correlated with both tax rates and smoking. Since there is so little variation in the tax rate within states in our sample, however, the absence of an effect in the long form might simply reflect limitations of the design. Further research, with longer time frames and better measures of other state and region-specific factors, will help resolve this issue.

Our findings can be summarized as follows: the health care costs of smoking initiation, and the health care benefits of smoking cessation, may be greater than previously believed. If taxes or other regulations affect these aspects of smoking status, then they will have effects beyond the revenue effects currently discussed in the policy arena. In particular, they may reduce future costs, as well as provide a means of financing existing costs of smoking, by leading to reductions in both initiation and cessation. 


\section{References}

Angrist, Joshua, Guido W. Imbens, and Donald B. Rubin (1996), "Identification of Causal Effects Using Instrumental Variables," Journal of the American Statistical Association, 91(434):444-455.

Bartecchi, C. E., T. D. MacKenzie, and R.W. Schrier (1994), "The Human Costs of Tobacco Use (part 1)," New England Journal of Medicine, 330(13): 907-912.

Becker, Gary S., Michael Grossman, and Kevin M. Murphy (1994), "An Empirical Analysis of Cigarette Addiction," American Economic Review, 84(3):396-418.

Chaloupka, Frank (1991), "Rational Addictive Behavior and the Effect of Price on Consumption," Journal of Political Economy, 99(4):722-741.

(1994), Clean Indoor Air Laws and Cigarette Smoking. Applied Economics, 24(2): 193-205.

, and Ken Warner (2000), "The Economics of Smoking," in Newhouse, J. and A.

Cuyler, Handbook of Health Economics.

Cook, Philip, and George Tauchen (1982), “The Effect of Liquor Taxes on Heavy Drinking." Bell Journal of Economics, 13(2): 379-390.

Evans, William, and Jeanne Ringel (1998), "Can Higher Cigarette Taxes Improve Birth Outcomes?" Journal of Public Economics.

Evans, William, and Matthew Farrelly (1995), "The Compensating Behavior of Smokers: Taxes, Tar, and Nicotine," RAND Journal of Economics.

Farrell, Philip, and Victor R. Fuchs (1982), "Schooling and Health: The Cigarette Connection," Journal of Health Economics 1:217-236.

Grossman, Michael (1989), "Health Benefits of Increases in Alcohol and Cigarette Taxes, ” British Journal of Addiction, 84(10):1193-1204.

Grossman, Michael, Jody Sindelar, John Mullahy, and Richard Anderson (1993), “Alcohol and Cigarette Taxes", Journal of Economic Perspectives, 7(4):211-222.

Harris, Jeffrey E. (1982), "Increasing the Federal Excise Tax on Cigarettes," Journal of Health Economics, 1:117-120.

(1987), "The 1983 Increase in the Federal Cigarette Excise Tax," in

Summers, L. H., ed., Tax Policy and the Economy, vol. 1, MIT Press: Cambridge, MA. 
(1994), “A Working Model for Predicting the Consumption and Revenue Impacts of Large Increases in the U.S. Federal Cigarette Excise Tax, NBER Working Paper No. 4803.

Kenkel, Donald S. (1991), "Health Behavior, Health Knowledge, and Schooling," Journal of Political Economy 99 (2): 287-305.

Manning, Willard, Emmett B. Keeler, Joseph P. Newhouse, Elizabeth M. Sloss, and Jefferey Wasserman (1989). "The Taxes of Sin: Do Smokers and Drinkers Pay Their Way?” JAMA, 261:1604-1609.

Manning, Willard, Emmett B. Keeler, Joseph P. Newhouse, Elizabeth M. Sloss, and Jefferey Wasserman (1993), The Costs of Poor Health Habits, Cambridge, MA: Harvard University Press.

Moore, Michael J. (1996), "Death and Tobacco Taxes," RAND Journal of Economics. (2000), "Passive Smoking: Health Perceptions Myth vs. Health Care Reality." Forthcoming, Journal of Risk and Uncertainty. , and J.W. Hughes (2000), "The Role of Coefficient Covariances in Recursive Health Policy Simulations.” Unpublished working paper.

Peltzman, Sam (1975), "The Economics of Automobile Safety Regulation." Journal of Political Economy, 83: 677-725.

Rodgers, Gregory (1996), "The Mortality Effects of Child-Resistant Packaging: 25 Years of Experience." Journal of the American Medical Association, 275 (21): 1661-65.

Tobacco Institute, 1993, Tax Burden on Tobacco.

Tollison, R.D., and R.E. Wagner (1992), The Economics of Smoking (Boston Kluwer Academic Publishers).

United States Department of Health and Human Services (1990). The Health Benefits of Smoking Cessation: A Report of the Surgeon General, U.S. Government Printing Office.

Viscusi, W. Kip (1992). Smoking: Making the Risky Decision. Cambridge: Harvard University Press.

(1984). "The Lulling Effect: The Impact of Child Resistant Packaging on Aspirin and Analgesic Injections." Journal of Law and Economics, 28(2): 527-554.

(1994), "Cigarette Taxation and the Social Consequences of Smoking," in J. Poterba, ed., Tax Policy and the Economy, vol. 9 Cambridge, MA: NBER. 
Warner, Ken E. (1986), "Smoking and Health Implications of a Change in the Federal Cigarette Excise Tax, Journal of the American Medical Association, 255(8): 1028-32. 
Figure 1

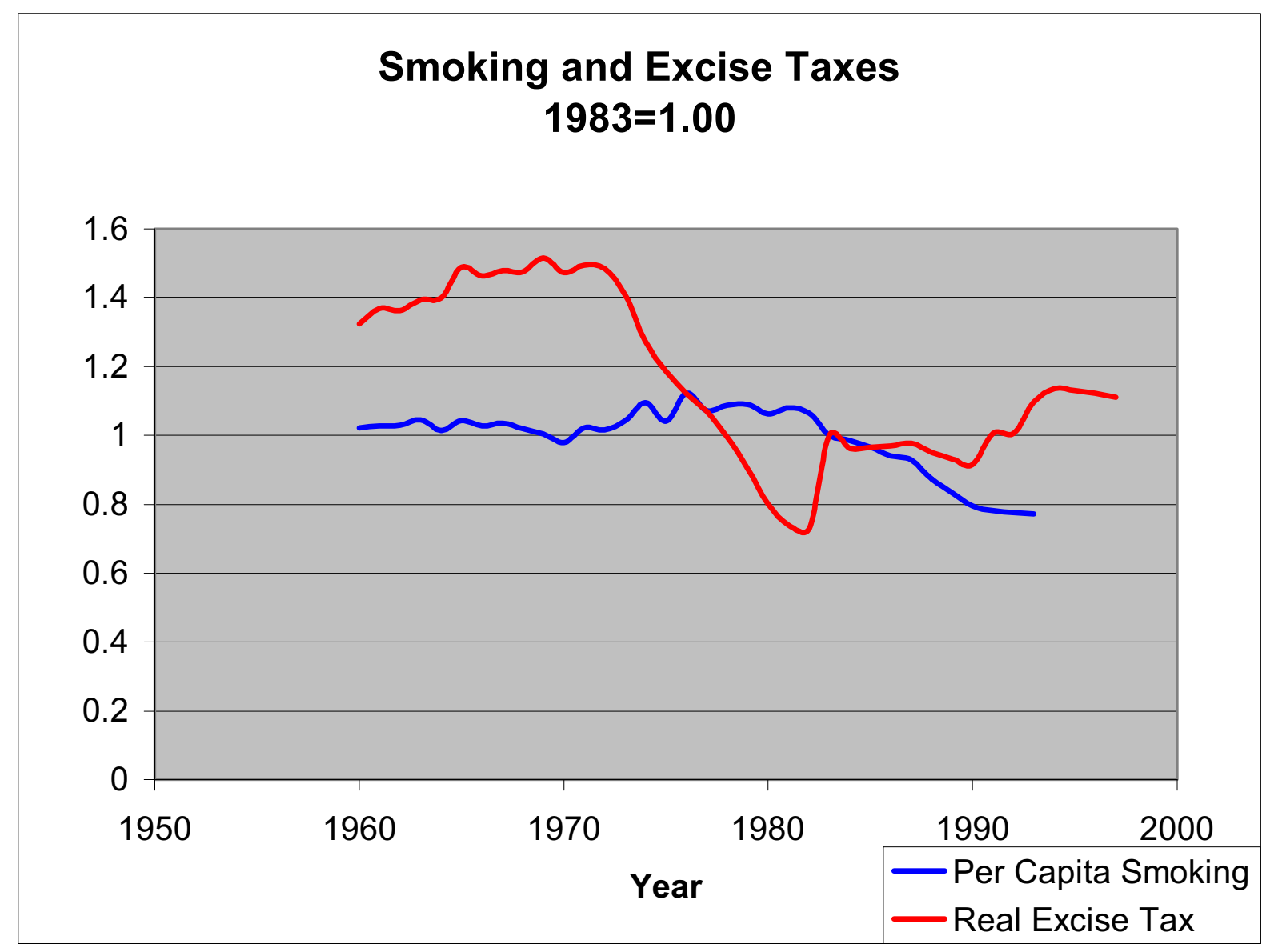


Table 1

Descriptive Statistics, States, 1954-88

Per capita tobacco consumption

124.44

(Packs per person per year)

(29.68)

Price of cigarettes per pack

50.79

(Nominal)

State and Federal excise tax per pack

19.42

(Nominal)

State per capita income

5106.54

(Nominal)

Age 45-64

0.183

(\% of state population)

Age 65 or more

(\% of state population)

Mortality rate-smoking related diagnoses

(Heart disease, cancers of lung, mouth, \& throat)

Mortality rate-all causes

904.50

(110.67)

Sample Size (48 states, 1954-88)

1680

Sources: Tobacco consumption, price, and tax data from Tax Burden on Tobacco, 1993. Per capita income from Survey of Current Business, various years. Mortality data from Vital Statistics of the United States, Annual Summary, various years. Age mix data from Statistical Abstract of the United States, various years. 


\section{Table 2a}

Aggregate Mortality and Smoking, States, 1954-88

Structural Model Estimates

\begin{tabular}{ccccc}
\hline & \multicolumn{2}{c}{ OLS Estimates $^{\mathrm{a}}$} & \multicolumn{2}{c}{ 2SLS Estimates $^{\mathrm{a}, \mathrm{b}}$} \\
\hline & $\begin{array}{c}\text { Total } \\
\text { Deaths }\end{array}$ & $\begin{array}{c}\text { Smoking } \\
\text { Deaths }\end{array}$ & $\begin{array}{c}\text { Total } \\
\text { Deaths }\end{array}$ & $\begin{array}{c}\text { Smoking } \\
\text { Deaths }\end{array}$ \\
\hline Smoking & 0.464 & 0.387 & 0.795 & 0.753 \\
$\begin{array}{c}\text { (Per capita } \\
\text { packs) }\end{array}$ & $(0.067)$ & $(0.050)$ & $(0.165)$ & $(0.122)$ \\
\hline Real Income & 0.003 & -0.005 & 0.002 & -0.005 \\
& $(0.002)$ & $(0.003)$ & $(0.002)$ & $(0.002)$ \\
Adjusted R- & 0.910 & 0.928 & 0.908 & 0.926 \\
squared & & & & \\
\hline
\end{tabular}

${ }^{\mathrm{a}}$ Additional control variables include dummy indicators of state and year, and two age mix variables.

${ }^{\mathrm{b}}$ Identifying instrumental variable is state-year real cigarette excise tax. 
Table 2b

Aggregate Mortality and Smoking, States, 1954-88

First-stage and Reduced Form Estimates

\begin{tabular}{|c|c|c|c|}
\hline & \multicolumn{3}{|c|}{ Dependent Variable } \\
\hline & $\begin{array}{l}\text { Per Capita } \\
\text { Smoking }^{\text {a }}\end{array}$ & $\begin{array}{c}\text { Total } \\
\text { Deaths }^{\mathrm{a}}\end{array}$ & $\begin{array}{l}\text { Smoking } \\
\text { Deaths }^{\mathrm{a}}\end{array}$ \\
\hline Cigarette Tax & $\begin{array}{l}-1.266 \\
(0.071)\end{array}$ & $\begin{array}{l}-1.072 \\
(0.199)\end{array}$ & $\begin{array}{l}-0.989 \\
(0.145)\end{array}$ \\
\hline Real Income & $\begin{array}{l}1.0 \mathrm{E}-3 \\
(0.7 \mathrm{E}-3)\end{array}$ & $\begin{array}{c}0.002 \\
(0.002)\end{array}$ & $\begin{array}{l}-0.005 \\
(0.002)\end{array}$ \\
\hline $\begin{array}{l}\text { Adjusted R- } \\
\text { squared }\end{array}$ & 0.849 & 0.910 & 0.926 \\
\hline
\end{tabular}

${ }^{a}$ Additional control variables include dummy indicators of state and year, and two age mix variables. 
Table 3

Smoking Cessation and CHD Mortality

Selected Studies

\begin{tabular}{|c|c|c|c|c|}
\hline Reference & Population & $\begin{array}{l}\text { Smoking Status } \\
\text { and years since quit }\end{array}$ & $\begin{array}{l}\text { Mortality } \\
\text { Ratio }\end{array}$ & Comments \\
\hline \multirow[t]{2}{*}{$\begin{array}{l}\text { Doll and Hill } \\
\text { (1964) }\end{array}$} & $\begin{array}{l}\text { British drs, } \\
\text { males } \\
(\mathrm{P}: \mathrm{N}=34,445)\end{array}$ & Current & 1.41 & \\
\hline & & $\begin{array}{l}\text { Former } \\
1-4 \\
5-9 \\
10-14 \\
15+\end{array}$ & $\begin{array}{l}1.05 \\
1.25 \\
1.16 \\
1.12\end{array}$ & \\
\hline \multirow[t]{16}{*}{$\begin{array}{l}\text { Doll and Peto } \\
\text { (1976) }\end{array}$} & $\begin{array}{l}\text { British drs, } \\
\text { males } \\
(\mathrm{P}: \mathrm{N}=34,440)\end{array}$ & Aged 30-54 & & \\
\hline & & $\begin{array}{l}\text { Current } \\
\text { Former }\end{array}$ & 3.5 & \\
\hline & & $1-4$ & 1.9 & \\
\hline & & $5-9$ & 1.3 & \\
\hline & & $10-14$ & 1.4 & \\
\hline & & $\begin{array}{l}15+ \\
\text { Aged 55-64 }\end{array}$ & 1.3 & \\
\hline & & $\begin{array}{l}\text { Current } \\
\text { Former }\end{array}$ & 1.7 & \\
\hline & & $1-4$ & 1.9 & \\
\hline & & $5-9$ & 1.4 & \\
\hline & & $10-14$ & 1.7 & \\
\hline & & $\begin{array}{c}15+ \\
\text { Aged } 65+\end{array}$ & 1.3 & \\
\hline & & $\begin{array}{l}\text { Current } \\
\text { Former }\end{array}$ & 1.3 & \\
\hline & & $1-4$ & 1.0 & \\
\hline & & $5-9$ & 1.3 & \\
\hline & & $10-14$ & 1.2 & \\
\hline & & $15+$ & 1.1 & \\
\hline Hammond and & Men age $50-60$ & & & \\
\hline \multirow[t]{6}{*}{ Horn $(1958 a, b)$} & $(\mathrm{P}: \mathrm{N}=187,783)$ & $<1$ pack/day & & \\
\hline & & $\begin{array}{l}\text { Current } \\
\text { Former }\end{array}$ & 1.75 & \\
\hline & & $<1$ year & 2.09 & \\
\hline & & $1-10$ & 1.54 & \\
\hline & & $\begin{aligned} & 10+ \\
> & 1 \mathrm{pack} / \mathrm{day}\end{aligned}$ & 1.09 & \\
\hline & & Current & 2.20 & \\
\hline
\end{tabular}




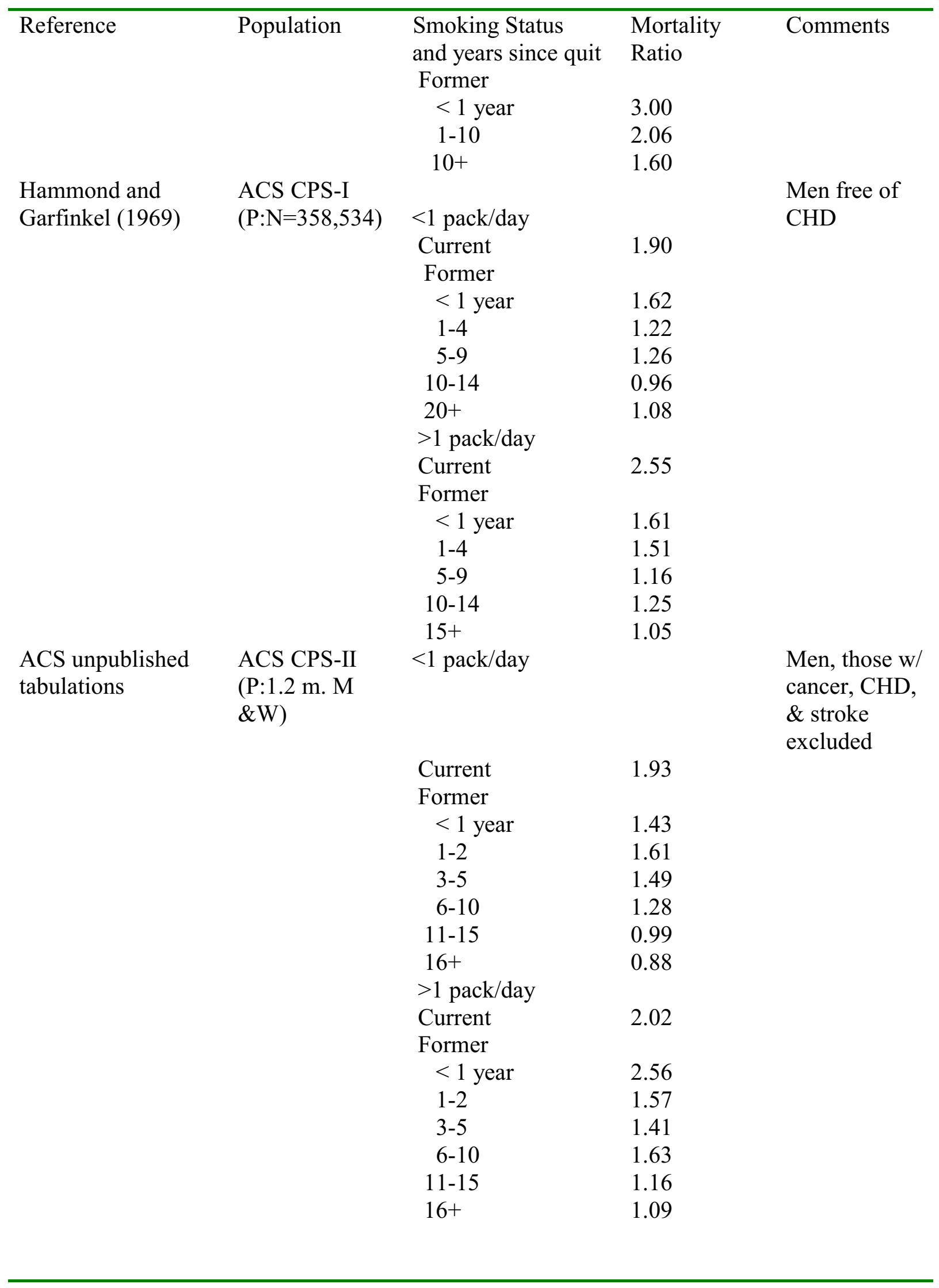


Table 4

Smoking Cessation and Lung Cancer

Selected Studies

\begin{tabular}{|c|c|c|c|c|c|}
\hline Reference & Population & $\begin{array}{l}\text { Smoking Status } \\
\text { and years since quit }\end{array}$ & $\begin{array}{l}\text { Mortal } \\
\text { Ratio }\end{array}$ & & Comments \\
\hline $\begin{array}{l}\text { Doll and Peto } \\
\text { (1976) }\end{array}$ & $\begin{array}{l}\text { British drs. } \\
(\mathrm{P}: \mathrm{N}=34,440)\end{array}$ & $\begin{array}{l}\text { Never } \\
\text { Current } \\
\text { Former } \\
1-4 \\
5-9 \\
10-14 \\
14+\end{array}$ & $\begin{array}{l}1.0 \\
15.8 \\
\\
16.0 \\
5.9 \\
5.3 \\
2.0\end{array}$ & & \\
\hline $\begin{array}{l}\text { Rogot and Murray } \\
(1980)\end{array}$ & U.S. Veterans & $\begin{array}{l}\text { Current } \\
\text { Former } \\
1-4 \\
5-9 \\
10-14 \\
15-19 \\
20+\end{array}$ & $\begin{array}{l}11.3 \\
\\
18.8 \\
7.7 \\
4.7 \\
4.8 \\
2.1\end{array}$ & & $\begin{array}{l}\text { "Drs. Orders" } \\
\text { quitters } \\
\text { excluded }\end{array}$ \\
\hline US DHHS & Japanese Males & $\begin{array}{l}\text { Current } \\
\text { Former } \\
1-4 \\
5-9 \\
10+\end{array}$ & $\begin{array}{l}3.8 \\
\\
4.7 \\
2.5 \\
1.4\end{array}$ & & \\
\hline Hammond (1966) & $\begin{array}{l}\text { ACS CPS-I } \\
\text { males }\end{array}$ & $\begin{array}{l}\text { Never } \\
\text { Current } \\
\text { Former } \\
<1 \\
1-4 \\
5-9 \\
10+\end{array}$ & $\begin{array}{l}<20 / \\
\text { day } \\
1.0 \\
6.5 \\
7.2 \\
4.6 \\
1.0 \\
0.4\end{array}$ & $\begin{array}{l}20+ \\
/ \text { day } \\
1.0 \\
\\
\\
29.1 \\
12.0 \\
7.2 \\
1.1\end{array}$ & \\
\hline $\begin{array}{l}\text { ACS (unpublished } \\
\text { tabulations) }\end{array}$ & $\begin{array}{l}\text { ACS CPS-II } \\
\text { males }\end{array}$ & $\begin{array}{l}\text { Never } \\
\text { Current } \\
\text { Former }\end{array}$ & $\begin{array}{l}1.0 \\
18.8\end{array}$ & $\begin{array}{l}1.0 \\
26.9\end{array}$ & \\
\hline
\end{tabular}




\begin{tabular}{lllll}
\hline Reference & Population & Smoking Status and & Mortality & Comments \\
& & years since quit & Ratio & \\
& & 1 & 26.7 & 50.7 \\
& $1-2$ & 22.4 & 33.2 \\
& $3-5$ & 16.5 & 20.9 \\
& & $6-10$ & 8.7 & 15.0 \\
ACS (unpublished & $11-15$ & 6.0 & 12.6 \\
tabulations) & ACS CPS-II & & 3.1 & 5.5 \\
& females & Never & & \\
& & Current & 1.0 & 1.0 \\
& & Former & 7.3 & 16.3 \\
& & & \\
& & 1 & 7.9 & 34.3 \\
& & $1-2$ & 9.1 & 19.5 \\
& & 2.9 & 14.6 \\
& & $6-10$ & 1.0 & 9.1 \\
& & $11-15$ & 1.5 & 5.9 \\
\hline
\end{tabular}


Table 5

Smoking Cessation and Oral Cancer

Selected Studies

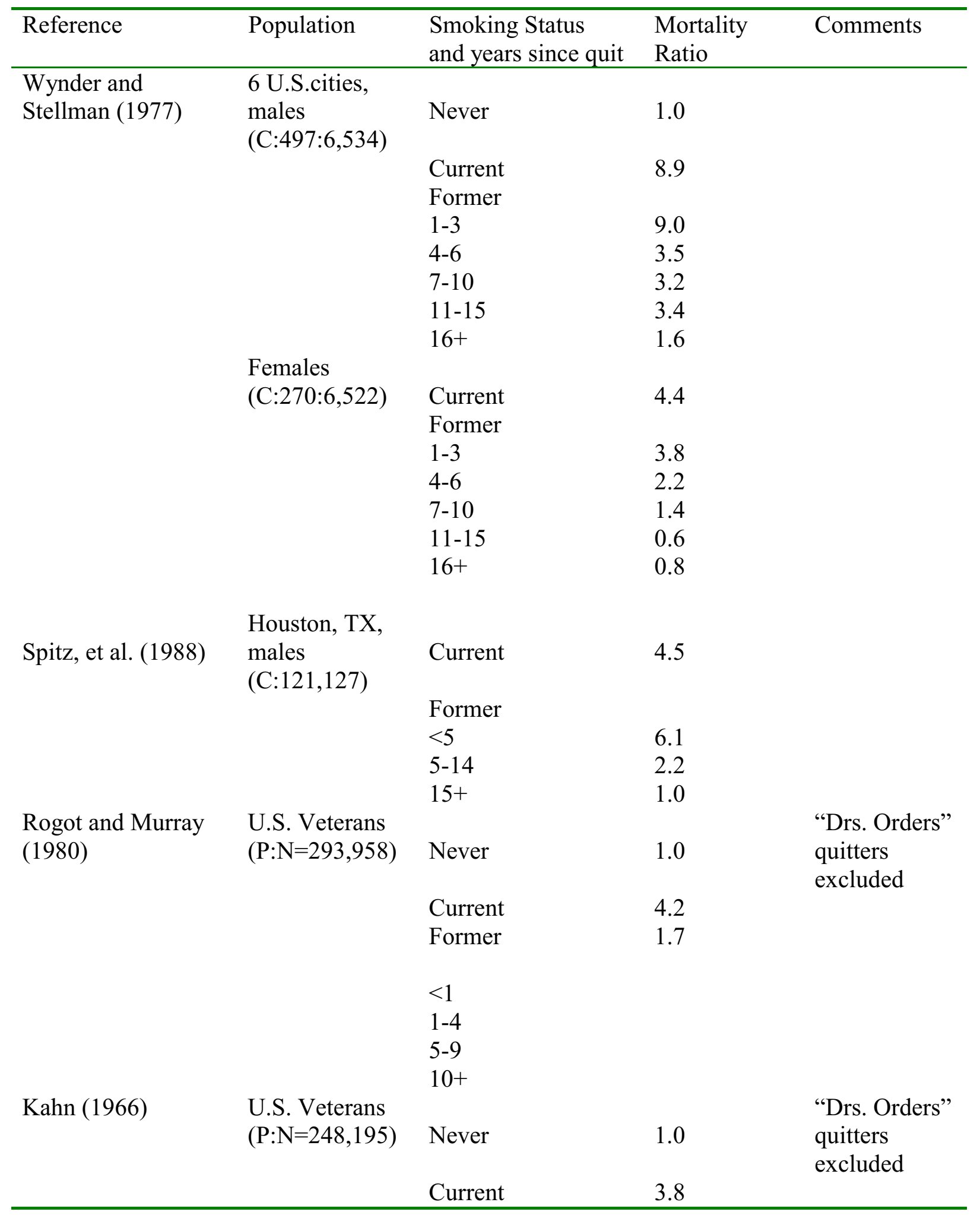


Table 6

Variable Definitions

\begin{tabular}{|c|c|}
\hline Variable & Definition \\
\hline \multicolumn{2}{|l|}{ Health outcomes } \\
\hline Doctor visits & Number of doctor visits in past 12 months \\
\hline Hospital days & $\begin{array}{l}\text { Number of short stay hospital days in past } 12 \text { months excluding } \\
\text { delivery }\end{array}$ \\
\hline Hospital episodes & $\begin{array}{l}\text { Number of short stay hospital episodes in past } 12 \text { months } \\
\text { excluding delivery }\end{array}$ \\
\hline Hospital days per episode & Hospital days per episodes (nearest integer) \\
\hline Lost Workdays & Days absent from work due to injury or illness \\
\hline \multicolumn{2}{|l|}{ Demographic Characteristics } \\
\hline Male & 1 if male \\
\hline Black & 1 if black \\
\hline \multicolumn{2}{|l|}{ Age } \\
\hline Age 18-21 & Age dummy variable \\
\hline Age 22-25 & Age d.v. \\
\hline Age $26-30$ & Age d.v. \\
\hline Age $31-35$ & Age d.v. \\
\hline Age $36-45$ & Age d.v. \\
\hline Age $46-55$ & Age d.v. \\
\hline Age $56-65$ & Age d.v. \\
\hline \multicolumn{2}{|l|}{ Schooling level } \\
\hline Less than high school & 1 if education $<12$ years \\
\hline High school & 1 if education $=12-15$ years \\
\hline College & 1 if education $>16$ years \\
\hline \multicolumn{2}{|l|}{ Income level } \\
\hline Income $<10000$ & Family income d.v. \\
\hline $10000<$ Income $<20000$ & Family income d.v. \\
\hline $20000<$ Income $<30000$ & Family income d.v. \\
\hline $30000<$ Income $<40000$ & Family income d.v. \\
\hline $40000<$ Income $<50000$ & Family income d.v. \\
\hline $50000<$ Income & Family income d.v. \\
\hline Income missing & 1 if family income missing, \\
\hline \multicolumn{2}{|l|}{ Marital status } \\
\hline Single & Marital status: 1 if never married \\
\hline Widowed & Marital status d.v. \\
\hline
\end{tabular}


Divorced or separated

Married

Bmi

Family size

\section{Employment status}

Working in public sector

Working in private sector

Self rated health status

Excellent Health

Very good health

Good health

Fair health

Poor health

Seat belt user

Cigarettes per day

\section{Health insurance}

Private insurance

Public insurance

\section{Region}

North

South

Midwest

West
Marital status d.v.

Marital status d.v.

Body mass index
1 if working in public sector

1 if working in private sector

1 if health self-reported as excellent

1 if health self-reported as very good

1 if health self-reported as good

1 if health self-reported as fair

1 if health self-reported as poor

1 if wears seat belt regularly

Number of cigarettes smoked per day, smokers only

1 if private insurance

1 if medicare, medicaid, army, or other public insurance

Region d.v.

Region d.v.

Region d.v.

Region d.v. 
Table 7

Descriptive Characteristics

1991 \& 1993 National Health Interview Surveys ${ }^{\text {a }}$

\begin{tabular}{|c|c|c|c|}
\hline Variable & $\begin{array}{r}\text { Never } \\
\text { Smoker } \\
(\mathrm{N}=21596)\end{array}$ & $\begin{array}{r}\text { Former } \\
\text { Smoker } \\
(\mathrm{N}=10220)\end{array}$ & $\begin{array}{r}\text { Current } \\
\text { Smoker } \\
(\mathrm{N}=11197)\end{array}$ \\
\hline Health outcomes & $\begin{array}{r}\text { Mean } \\
\text { (Std. Dev.) }\end{array}$ & $\begin{array}{r}\text { Mean } \\
\text { (Std. Dev.) }\end{array}$ & $\begin{array}{r}\text { Mean } \\
\text { (Std. Dev.) }\end{array}$ \\
\hline Doctor visits & $\begin{array}{r}4.112 \\
(10.135)\end{array}$ & $\begin{array}{r}5.222 \\
(14.433)\end{array}$ & $\begin{array}{r}4.490 \\
(13.440)\end{array}$ \\
\hline Hospital days & $\begin{array}{r}0.508 \\
(3.588)\end{array}$ & $\begin{array}{r}1.024 \\
(5.869)\end{array}$ & $\begin{array}{r}0.622 \\
(4.362)\end{array}$ \\
\hline Hospital episodes & $\begin{array}{r}0.081 \\
(0.357)\end{array}$ & $\begin{array}{r}0.146 \\
(0.516)\end{array}$ & $\begin{array}{r}0.101 \\
(0.410)\end{array}$ \\
\hline Lost Workdays & $\begin{array}{r}0.118 \\
(0.882)\end{array}$ & $\begin{array}{r}0.144 \\
(1.032)\end{array}$ & $\begin{array}{r}0.181 \\
(1.164)\end{array}$ \\
\hline Personal Character & & & \\
\hline Male & $\begin{array}{r}0.397 \\
(0.489)\end{array}$ & $\begin{array}{r}0.587 \\
(0.492)\end{array}$ & $\begin{array}{r}0.519 \\
(0.500)\end{array}$ \\
\hline Black & $\begin{array}{r}0.124 \\
(0.331)\end{array}$ & $\begin{array}{r}0.067 \\
(0.251)\end{array}$ & $\begin{array}{r}0.127 \\
(0.333)\end{array}$ \\
\hline Age & $\begin{array}{r}42.361 \\
(18.729)\end{array}$ & $\begin{array}{r}51.049 \\
(16.617)\end{array}$ & $\begin{array}{r}40.979 \\
(14.735)\end{array}$ \\
\hline Age $18-21$ & $\begin{array}{r}0.110 \\
(0.312)\end{array}$ & $\begin{array}{r}0.017 \\
(0.131)\end{array}$ & $\begin{array}{r}0.064 \\
(0.244)\end{array}$ \\
\hline Age $22-25$ & $\begin{array}{r}0.100 \\
(0.300)\end{array}$ & $\begin{array}{r}0.037 \\
(0.188)\end{array}$ & $\begin{array}{r}0.792 \\
(0.270)\end{array}$ \\
\hline Age $26-30$ & $\begin{array}{r}0.124 \\
(0.330)\end{array}$ & $\begin{array}{r}0.063 \\
(0.243)\end{array}$ & $\begin{array}{r}0.133 \\
(0.340)\end{array}$ \\
\hline Age $31-35$ & $\begin{array}{r}0.120 \\
(0.325)\end{array}$ & $\begin{array}{r}0.090 \\
(0.287)\end{array}$ & $\begin{array}{r}0.148 \\
(0.355)\end{array}$ \\
\hline Age $36-45$ & $\begin{array}{r}0.187 \\
(0.389)\end{array}$ & $\begin{array}{r}0.208 \\
(0.406)\end{array}$ & $\begin{array}{r}0.240 \\
(0.427)\end{array}$ \\
\hline Age $46-55$ & $\begin{array}{r}0.107 \\
(0.289)\end{array}$ & $\begin{array}{r}0.174 \\
(0.379)\end{array}$ & $\begin{array}{r}0.156 \\
(0.363)\end{array}$ \\
\hline Age $56-65$ & $\begin{array}{r}0.092 \\
(0.290)\end{array}$ & $\begin{array}{r}0.177 \\
(0.381)\end{array}$ & $\begin{array}{r}0.060 \\
(0.237)\end{array}$ \\
\hline
\end{tabular}

Schooling level

\begin{tabular}{lrrr} 
Less than high school & 0.185 & 0.197 & 0.257 \\
& $(0.388)$ & $(0.397)$ & $(0.437)$ \\
High school & 0.571 & 0.578 & 0.634 \\
& $(0.495)$ & $(0.494)$ & $(0.482)$ \\
College & 0.103 & 0.099 & 0.041 \\
\hline
\end{tabular}




\begin{tabular}{|c|c|c|c|}
\hline & $(0.304)$ & $(0.298)$ & $(0.198)$ \\
\hline \multicolumn{4}{|l|}{ Income level } \\
\hline \multirow[t]{2}{*}{ Income $<10000$} & 0.104 & 0.066 & 0.121 \\
\hline & $(0.305)$ & $(0.248)$ & $(0.326)$ \\
\hline \multirow[t]{2}{*}{$10000<$ Income $<20000$} & 0.151 & 0.147 & 0.177 \\
\hline & $(0.358)$ & $(0.354)$ & $(0.381)$ \\
\hline \multirow{2}{*}{$20000<$ Income $<30000$} & 0.138 & 0.144 & 0.166 \\
\hline & $(0.345)$ & $(0.351)$ & $(0.372)$ \\
\hline \multirow[t]{2}{*}{$30000<$ Income $<40000$} & 0.127 & 0.132 & 0.128 \\
\hline & $(0.333)$ & $(0.338)$ & $(0.344)$ \\
\hline \multirow[t]{2}{*}{$40000<$ Income $<50000$} & 0.098 & 0.114 & 0.097 \\
\hline & $(0.298)$ & $(0.317)$ & $(0.296)$ \\
\hline \multirow[t]{2}{*}{$50000<$ Income } & 0.213 & 0.244 & 0.158 \\
\hline & $(0.410)$ & $(0.429)$ & $(0.364)$ \\
\hline \multirow[t]{2}{*}{ Income missing } & 0.169 & 0.154 & 0.154 \\
\hline & $(0.375)$ & $(0.361)$ & $(0.361)$ \\
\hline \multicolumn{4}{|l|}{ Marital status } \\
\hline \multirow[t]{2}{*}{ Single } & 0.238 & 0.085 & 0.179 \\
\hline & $(0.426)$ & $(0.280)$ & $(0.384)$ \\
\hline \multirow[t]{2}{*}{ Widowed } & 0.082 & 0.076 & 0.049 \\
\hline & $(0.276)$ & $(0.265)$ & $(0.217)$ \\
\hline \multirow{2}{*}{ Divorced or separated } & 0.070 & 0.088 & 0.144 \\
\hline & $(0.254)$ & $(0.284)$ & $(0.352)$ \\
\hline \multirow[t]{2}{*}{ Married } & 0.609 & 0.750 & 0.627 \\
\hline & $(0.487)$ & $(0.433)$ & $(0.484)$ \\
\hline \multirow[t]{2}{*}{$\mathrm{Bmi}$} & 25.213 & 26.137 & 24.866 \\
\hline & $(4.917)$ & $(4.734)$ & $(4.655)$ \\
\hline \multirow[t]{2}{*}{ Family size } & 2.948 & 2.730 & 2.968 \\
\hline & $(1.675)$ & $(1.395)$ & $(1.597)$ \\
\hline \multicolumn{4}{|l|}{ Employment status } \\
\hline \multirow[t]{2}{*}{ Working in public sector } & 0.113 & 0.097 & 0.082 \\
\hline & $(0.317)$ & $(0.296)$ & $(0.275)$ \\
\hline \multirow[t]{2}{*}{ Working in private sector } & 0.469 & 0.419 & 0.555 \\
\hline & $(0.499)$ & $(0.493)$ & $(0.497)$ \\
\hline \multicolumn{4}{|l|}{ Self rated health status } \\
\hline \multirow[t]{2}{*}{ Excellent Health } & 0.372 & 0.320 & 0.285 \\
\hline & $(0.483)$ & $(0.466)$ & $(0.451)$ \\
\hline \multirow[t]{2}{*}{ Very good health } & 0.295 & 0.284 & 0.289 \\
\hline & $(0.456)$ & $(0.451)$ & $(0.453)$ \\
\hline \multirow[t]{2}{*}{ Good health } & 0.236 & 0.249 & 0.280 \\
\hline & $(0.424)$ & $(0.433)$ & $(0.449)$ \\
\hline \multirow[t]{2}{*}{ Fair health } & 0.073 & 0.104 & 0.104 \\
\hline & $(0.260)$ & $(0.305)$ & $(0.306)$ \\
\hline
\end{tabular}




\begin{tabular}{|c|c|c|c|}
\hline Poor health & $\begin{array}{r}0.024 \\
(0.152)\end{array}$ & $\begin{array}{r}0.043 \\
(0.204)\end{array}$ & $\begin{array}{r}0.042 \\
(0.200)\end{array}$ \\
\hline Seat belt user & $\begin{array}{r}0.758 \\
(0.429)\end{array}$ & $\begin{array}{r}0.589 \\
(0.492)\end{array}$ & $\begin{array}{r}0.740 \\
(0.439)\end{array}$ \\
\hline Cigarettes per day & $\begin{array}{r}0.000 \\
(0)\end{array}$ & $\begin{array}{r}0.014 \\
(0.261)\end{array}$ & $\begin{array}{r}17.982 \\
(11.489)\end{array}$ \\
\hline \multicolumn{4}{|l|}{ Health insurance } \\
\hline Private insurance & $\begin{array}{r}0.781 \\
(0.414)\end{array}$ & $\begin{array}{r}0.838 \\
(0.368)\end{array}$ & $\begin{array}{r}0.688 \\
(0.463)\end{array}$ \\
\hline Public insurance & $\begin{array}{r}0.229 \\
(0.420)\end{array}$ & $\begin{array}{r}0.311 \\
(0.463)\end{array}$ & $\begin{array}{r}0.204 \\
(0.403)\end{array}$ \\
\hline \multicolumn{4}{|l|}{ Region } \\
\hline North & $\begin{array}{r}0.204 \\
(0.403)\end{array}$ & $\begin{array}{r}0.228 \\
(0.420)\end{array}$ & $\begin{array}{r}0.195 \\
(0.396)\end{array}$ \\
\hline South & $\begin{array}{r}0.333 \\
(0.471)\end{array}$ & $\begin{array}{r}0.305 \\
(0.460)\end{array}$ & $\begin{array}{r}0.345 \\
(0.475)\end{array}$ \\
\hline Midwest & $\begin{array}{r}0.239 \\
(0.427)\end{array}$ & $\begin{array}{r}0.243 \\
(0.429)\end{array}$ & $\begin{array}{r}0.261 \\
(0.439)\end{array}$ \\
\hline West & $\begin{array}{r}0.224 \\
(0.471)\end{array}$ & $\begin{array}{r}0.223 \\
(0.416)\end{array}$ & $\begin{array}{r}0.199 \\
(0.400)\end{array}$ \\
\hline
\end{tabular}

${ }^{\mathrm{a}}$ Weighted data from pooled 1991 and 1993 National Health Interview Surveys. 
Table 8

Smoking prevalence by socio-demographic groups,

Full Sample

1991-1993 NHIS ${ }^{\text {a }}$

\begin{tabular}{|c|c|c|c|}
\hline Subgroup & $\begin{array}{l}\text { Never } \\
\text { Smoker } \\
(\%)\end{array}$ & $\begin{array}{l}\text { Former } \\
\text { Smoker } \\
(\%)\end{array}$ & $\begin{array}{l}\text { Current } \\
\text { Smoker } \\
(\%)\end{array}$ \\
\hline All sample & 0.502 & 0.241 & 0.256 \\
\hline \multicolumn{4}{|l|}{ Males aged } \\
\hline $18-25$ & 0.256 & 0.045 & 0.140 \\
\hline $26-35$ & 0.285 & 0.130 & 0.284 \\
\hline $36-45$ & 0.190 & 0.208 & 0.249 \\
\hline $46-55$ & 0.092 & 0.178 & 0.155 \\
\hline $56-65$ & 0.077 & 0.187 & 0.097 \\
\hline \multicolumn{4}{|l|}{ Females aged } \\
\hline $18-25$ & 0.178 & 0.064 & 0.145 \\
\hline $26-35$ & 0.218 & 0.185 & 0.276 \\
\hline $36-45$ & 0.184 & 0.208 & 0.231 \\
\hline $46-55$ & 0.117 & 0.169 & 0.156 \\
\hline $56-65$ & 0.103 & 0.161 & 0.106 \\
\hline \multicolumn{4}{|l|}{ Race } \\
\hline White & 0.875 & 0.932 & 0.873 \\
\hline Black & 0.125 & 0.068 & 0.127 \\
\hline \multicolumn{4}{|l|}{ Years of } \\
\hline \multicolumn{4}{|l|}{ Schooling } \\
\hline $0-11$ & 0.185 & 0.197 & 0.267 \\
\hline 12 & 0.349 & 0.366 & 0.440 \\
\hline $13-15$ & 0.221 & 0.212 & 0.194 \\
\hline 16 & 0.141 & 0.126 & 0.679 \\
\hline More than 16 & 0.102 & 0.099 & 0.041 \\
\hline
\end{tabular}

a. Weighted means, not adjusted for age or sex 
Table 9

Smoking and Health Care Utilization 1991 \& 1993 National Health Interview Surveys ${ }^{a}$

\begin{tabular}{lcccc}
\hline Variable & \multicolumn{2}{c}{ Working $^{\mathrm{b}}$} & \multicolumn{2}{c}{ Not Working $^{\mathrm{b}}$} \\
Hospital & Short Form $^{\mathrm{c}}$ & Long Form $^{\mathrm{d}}$ & Short Form $^{\mathrm{c}}$ & Long Form $^{\mathrm{d}}$ \\
Episodes & & & & \\
Current & & & & \\
& 1.259 & 1.211 & 1.555 & 1.259 \\
Former & $(3.935)$ & $(2.590)$ & $(6.219)$ & $(2.537)$ \\
& 1.263 & 1.218 & 1.632 & 1.594 \\
Hospital Days & $(3.562)$ & $(2.505)$ & $(6.125)$ & $(4.788)$ \\
Current & & & & \\
& 1.558 & 1.331 & 1.582 & 1.285 \\
Former & $(4.675)$ & $(2.369)$ & $(3.962)$ & $(1.649)$ \\
& 1.257 & 1.220 & 1.739 & 1.799 \\
Doctor Visits & $(2.146)$ & $(1.527)$ & $(4.126)$ & $(3.539)$ \\
& & & & \\
Current & 1.083 & 1.162 & 1.160 & 1.122 \\
& $(4.623)$ & $(6.666)$ & $(5.073)$ & $(3.099)$ \\
Former & 1.245 & 1.210 & 1.291 & 1.318 \\
& $(11.336)$ & $(7.944)$ & $(7.50)$ & $(6.728)$ \\
Lost Workdays & & & & \\
Current & 1.503 & 1.403 & & N.A. \\
& $(5.817)$ & $(3.738)$ & N.A. & N.A. \\
Former & 1.217 & 1.206 & N.A. & \\
& $(2.484)$ & $(1.914)$ & & \\
\hline
\end{tabular}

${ }^{a}$ Estimated coefficients from negative binomial regression models, reported as incidence rates, with asymptotic z-statistics on parentheses. Robust, cluster-corrected standard errors.

${ }^{\mathrm{b}} \mathrm{N}=24,646$ (short form); 23,913 (long form).

'Short form models include controls for age, race, and gender.

${ }^{\mathrm{d}}$ Long form models include short form variables, plus controls for private and/or public insurance coverage, seat belt use, body mass, education, income, region, marital status, and family size. 
Table 10

Smoking and Hospitalizations

Age-Specific Smoking Coefficient Estimates ${ }^{\text {a }}$

1991 \& 1993 National Health Interview Surveys

\begin{tabular}{lcccc}
\hline & \multicolumn{2}{c}{ Short Form } & \multicolumn{2}{c}{ Long Form } \\
Variable & Current & Former & Current & Former \\
Age 18-21 & 1.248 & 1.052 & 0.951 & 1.139 \\
& $(1.051)$ & $(0.146)$ & $(0.187)$ & $(0.395)$ \\
Age 22-25 & 1.683 & 1.953 & 1.215 & 2.263 \\
& $(2.320)$ & $(3.426)$ & $(0.782)$ & $(4.141)$ \\
Age 26-30 & 1.570 & 0.880 & 1.195 & 0.883 \\
& $(3.610)$ & $(0.608)$ & $(0.783)$ & $(0.579)$ \\
Age 31-35 & 1.260 & 1.220 & 0.947 & 0.877 \\
& $(1.684)$ & $(1.241)$ & $(0.475)$ & $(0.692)$ \\
Age 36-45 & & & & \\
& 1.675 & 1.364 & 1.373 & 1.237 \\
Age 46-55 & $(6.209)$ & $(2.983)$ & $(3.119)$ & $(1.947)$ \\
& & & & \\
Age 56-65 & 1.400 & 1.348 & 1.292 & 1.439 \\
& $(3.604)$ & $(2.452)$ & $(2.148)$ & $(2.738)$ \\
\hline Estimat) & & & 1.711 \\
& 1.330 & 1.650 & 1.272 & $(4.854)$ \\
\hline
\end{tabular}

${ }^{\mathrm{a}}$ Estimated coefficients from negative binomial regression models, reported as incidence rates, with asymptotic z-statistics on parentheses. Robust, cluster-corrected standard errors.

${ }^{\mathrm{b}} \mathrm{N}=24,646$ (short form); 23,913 (long form).

${ }^{\mathrm{c}}$ Short form models include controls for age, race, and gender.

${ }^{\mathrm{d}}$ Long form models include short form variables, plus controls for private and/or public insurance coverage, seat belt use, body mass, education, income, region, marital status, and family size. 
Table 11

Smoking and Hospital Days

Age-Specific Smoking Coefficient Estimates ${ }^{\text {a }}$

1991 \& 1993 National Health Interview Surveys

\begin{tabular}{lcccc}
\hline & \multicolumn{2}{c}{ Short Form } & \multicolumn{2}{c}{ Long Form } \\
Variable & Current & Former & Current & Former \\
Age 18-21 & 1.068 & 0.543 & 0.685 & 1.464 \\
& $(0.197)$ & $(1.206)$ & $(1.120)$ & $(0.699)$ \\
Age 22-25 & 2.010 & 3.279 & 1.304 & 4.221 \\
& $(2.655)$ & $(4.874)$ & $(0.757)$ & $(5.221)$ \\
Age 26-30 & 1.899 & 0.668 & 1.415 & 0.358 \\
& $(2.548)$ & $(1.184)$ & $(1.261)$ & $(0.418)$ \\
Age 31-35 & 1.704 & 1.804 & 1.094 & 1.228 \\
& $(2.956)$ & $(1.919)$ & $(0.596)$ & $(0.707)$ \\
Age 36-45 & & & & \\
& 1.929 & 1.277 & 1.254 & 1.018 \\
Age 46-55 & $(5.170)$ & $(1.426)$ & $(1.519)$ & $(0.106)$ \\
& & & & \\
Age 56-65 & 2.016 & 1.572 & 1.570 & 2.072 \\
& $(3.385)$ & $(2.504)$ & $(2.745)$ & $(4.739)$ \\
\hline Estimat) & & & 1.627 \\
& 1.215 & 1.788 & 1.226 & $(3.480)$ \\
\hline
\end{tabular}

${ }^{\mathrm{a}}$ Estimated coefficients from negative binomial regression models, reported as incidence rates, with asymptotic z-statistics on parentheses. Robust, cluster-corrected standard errors.

${ }^{\mathrm{b}} \mathrm{N}=24,646$ (short form); L3, 913 (long form).

${ }^{\mathrm{c}}$ Short form models include controls for age, race, and gender.

${ }^{\mathrm{d}}$ Long form models include short form variables, plus controls for private and/or public insurance coverage, seat belt use, body mass, education, income, region, marital status, and family size. 
Table 12

Smoking and Doctor Visits Age-Specific Smoking Coefficient Estimates ${ }^{\text {a }}$ 1991 \& 1993 National Health Interview Surveys

\begin{tabular}{|c|c|c|c|c|}
\hline \multirow[b]{2}{*}{ Variable } & \multicolumn{2}{|c|}{ Short Form } & \multicolumn{2}{|c|}{ Long Form } \\
\hline & Current & Former & Current & Former \\
\hline Age $18-21$ & $\begin{array}{c}1.033 \\
(0.307)\end{array}$ & $\begin{array}{c}1.241 \\
(1.851)\end{array}$ & $\begin{array}{c}1.174 \\
(1.150)\end{array}$ & $\begin{array}{c}1.025 \\
(0.220)\end{array}$ \\
\hline Age $22-25$ & $\begin{array}{c}1.203 \\
(2.364)\end{array}$ & $\begin{array}{c}1.108 \\
(1.280)\end{array}$ & $\begin{array}{c}1.184 \\
(2.691)\end{array}$ & $\begin{array}{c}1.085 \\
(0.941)\end{array}$ \\
\hline Age $26-30$ & $\begin{array}{c}1.169 \\
(1.646)\end{array}$ & $\begin{array}{c}1.263 \\
(1.903)\end{array}$ & $\begin{array}{c}1.245 \\
(2.484)\end{array}$ & $\begin{array}{c}1.165 \\
(1.107)\end{array}$ \\
\hline Age $31-35$ & $\begin{array}{c}1.125 \\
(1.591)\end{array}$ & $\begin{array}{c}1.223 \\
(2.150)\end{array}$ & $\begin{array}{c}1.186 \\
(2.497)\end{array}$ & $\begin{array}{c}1.325 \\
(2.716)\end{array}$ \\
\hline Age $36-45$ & $\begin{array}{c}1.221 \\
(3.856)\end{array}$ & $\begin{array}{c}1.243 \\
(3.873)\end{array}$ & $\begin{array}{c}1.061 \\
(1.243)\end{array}$ & $\begin{array}{c}1.209 \\
(3.172)\end{array}$ \\
\hline Age $46-55$ & $\begin{array}{c}1.148 \\
(2.152)\end{array}$ & $\begin{array}{c}1.284 \\
(4.734)\end{array}$ & $\begin{array}{c}1.153 \\
(1.790)\end{array}$ & $\begin{array}{c}1.262 \\
(3.015)\end{array}$ \\
\hline Age $56-65$ & $\begin{array}{c}1.192 \\
(1.755)\end{array}$ & $\begin{array}{c}1.347 \\
(4.583)\end{array}$ & $\begin{array}{c}1.122 \\
(1.300)\end{array}$ & $\begin{array}{c}1.315 \\
(2.880)\end{array}$ \\
\hline
\end{tabular}

${ }^{\mathrm{a}}$ Estimated coefficients from negative binomial regression models, reported as incidence rates, with asymptotic z-statistics on parentheses. Robust, cluster-corrected standard errors.

${ }^{b} \mathrm{~N}=.24,646$ (short form), 23, 913 (long form).

${ }^{\mathrm{c}}$ Short form models include controls for age, race, and gender.

${ }^{\mathrm{d}}$ Long form models include short form variables, plus controls for private and/or public insurance coverage, seat belt use, body mass, education, income, region, marital status, and family size. 
Table 13

Smoking and Lost Workdays

Age-Specific Smoking Coefficient Estimates ${ }^{\text {a }}$

1991 \& 1993 National Health Interview Surveys

\begin{tabular}{lcccc}
\hline & \multicolumn{2}{c}{ Short Form } & \multicolumn{2}{c}{ Long Form } \\
Variable & Current & Former & Current & Former \\
Age 18-21 & 1.070 & 0.786 & 0.867 & 0.653 \\
& $(0.429)$ & $(0.622)$ & $(0.503)$ & $(1.087)$ \\
Age 22-25 & 1.225 & 0.840 & 1.128 & 0.843 \\
& $(1.090)$ & $(0.712)$ & $(0.590)$ & $(0.504)$ \\
Age 26-30 & 1.611 & 1.185 & 1.528 & 1.262 \\
& $(3.034)$ & $(0.750)$ & $(1.805)$ & $(0.870)$ \\
Age 31-35 & 1.454 & 1.143 & 1.486 & 1.158 \\
& $(2.628)$ & $(0.716)$ & $(2.353)$ & $(0.520)$ \\
Age 36-45 & & & & \\
& 1.634 & 1.261 & 1.202 & 1.162 \\
Age 46-55 & $(4.809)$ & $(1.814)$ & $(1.146)$ & $(0.827)$ \\
& & & & \\
Age 56-65 & 1.194 & 1.305 & 1.324 & 1.508 \\
& $(1.228)$ & $(1.555)$ & $(1.550)$ & $(2.152)$ \\
\hline Estimat) & & & 1.391 \\
& 1.287 & 1.106 & 2.114 & $(1.326)$ \\
\hline
\end{tabular}

${ }^{\mathrm{a}}$ Estimated coefficients from negative binomial regression models, reported as incidence rates, with asymptotic z-statistics on parentheses. Robust, cluster-corrected standard errors.

${ }^{\mathrm{b}} \mathrm{N}=.24,646$ (short form), 23, 913 (long form).

${ }^{\mathrm{c}} \mathrm{S}$ hort form models include controls for age, race, and gender.

${ }^{\mathrm{d}}$ Long form models include short form variables, plus controls for private and/or public insurance coverage, seat belt use, body mass, education, income, region, marital status, and family size. 
Table 14

Smoking Status Models

Estimated Coefficients and Standard Errors ${ }^{\mathrm{a}}$

1991 \& 1993 National Health Interview Survey ${ }^{b}$

\begin{tabular}{|c|c|c|c|c|}
\hline \multirow{2}{*}{$\begin{array}{l}\text { Variable } \\
\text { Cigarette Tax }\end{array}$} & \multicolumn{2}{|c|}{ Never Smoked } & \multicolumn{2}{|c|}{\begin{tabular}{|l|l|l|} 
Former Smoker & Ever Smoked
\end{tabular}} \\
\hline & $\begin{array}{c}\text { Short Form }^{\mathrm{c}} \\
0.001 \\
(1.81)\end{array}$ & $\begin{array}{c}\text { Long Form }^{\mathrm{d}} \\
0.053 \\
(0.75)\end{array}$ & $\begin{array}{c}\text { Short Form }^{\mathrm{c}} \\
0.207 \\
(2.43)\end{array}$ & $\begin{array}{c}\text { Long Form }^{\mathrm{d}} \\
0.021 \\
(0.26)\end{array}$ \\
\hline Male & $\begin{array}{l}-0.115 \\
(18.69)\end{array}$ & $\begin{array}{l}-0.132 \\
(19.54)\end{array}$ & $\begin{array}{l}0.035 \\
(4.33)\end{array}$ & $\begin{array}{l}0.013 \\
(1.18)\end{array}$ \\
\hline Black & $\begin{array}{l}0.046 \\
(2.95)\end{array}$ & $\begin{array}{l}0.078 \\
(5.22)\end{array}$ & $\begin{array}{l}-0.154 \\
(12.63)\end{array}$ & $\begin{array}{l}-0.093 \\
(6.05)\end{array}$ \\
\hline Age $21-25$ & $\begin{array}{l}-0.089 \\
(7.45)\end{array}$ & $\begin{array}{l}-0.122 \\
(8.85)\end{array}$ & $\begin{array}{l}0.085 \\
(4.05)\end{array}$ & $\begin{array}{l}0.019 \\
(0.77)\end{array}$ \\
\hline Age $26-30$ & $\begin{array}{l}-0.156 \\
(11.92)\end{array}$ & $\begin{array}{l}-0.202 \\
(13.28)\end{array}$ & $\begin{array}{l}0.110 \\
(4.81)\end{array}$ & $\begin{array}{l}0.001 \\
(0.04)\end{array}$ \\
\hline Age $31-35$ & $\begin{array}{l}-0.223 \\
(17.51)\end{array}$ & $\begin{array}{l}-0.266 \\
(18.32)\end{array}$ & $\begin{array}{l}0.175 \\
(8.35)\end{array}$ & $\begin{array}{l}0.016 \\
(0.69)\end{array}$ \\
\hline Age $36-45$ & $\begin{array}{l}-0.253 \\
(18.88)\end{array}$ & $\begin{array}{l}-0.309 \\
(14.80)\end{array}$ & $\begin{array}{c}0.248 \\
(14.57)\end{array}$ & $\begin{array}{l}0.062 \\
(2.53)\end{array}$ \\
\hline Age 46-55 & $\begin{array}{l}-0.311 \\
(23.50)\end{array}$ & $\begin{array}{l}-0.337 \\
(19.67)\end{array}$ & $\begin{array}{c}0.311 \\
(15.46)\end{array}$ & $\begin{array}{l}0.128 \\
(5.24)\end{array}$ \\
\hline Age 56-65 & $\begin{array}{l}-0.307 \\
(17.90)\end{array}$ & $\begin{array}{l}-0.309 \\
(14.80)\end{array}$ & $\begin{array}{c}0.402 \\
(21.59)\end{array}$ & $\begin{array}{c}0.269 \\
(10.56)\end{array}$ \\
\hline $\begin{array}{l}\text { High School } \\
\text { Dropout }\end{array}$ & & $\begin{array}{l}-0.045 \\
(2.22)\end{array}$ & & $\begin{array}{l}-0.058 \\
(4.09)\end{array}$ \\
\hline Some College & & $\begin{array}{l}0.046 \\
(6.75)\end{array}$ & & $\begin{array}{l}0.071 \\
(5.63)\end{array}$ \\
\hline $\begin{array}{l}\text { College } \\
\text { Graduate }\end{array}$ & & $\begin{array}{c}0.171 \\
(17.73)\end{array}$ & & $\begin{array}{l}0.158 \\
(8.24)\end{array}$ \\
\hline College + & & $\begin{array}{c}0.201 \\
(14.28)\end{array}$ & & $\begin{array}{c}0.198 \\
(11.68)\end{array}$ \\
\hline Seat Belt User & & $\begin{array}{c}0.096 \\
(12.56)\end{array}$ & & $\begin{array}{c}0.105 \\
(11.46)\end{array}$ \\
\hline
\end{tabular}




\begin{tabular}{|c|c|c|}
\hline $\begin{array}{l}\text { Body Mass } \\
\text { Index }\end{array}$ & $\begin{array}{l}0.005 \\
(9.25)\end{array}$ & $\begin{array}{c}0.015 \\
(19.01)\end{array}$ \\
\hline $\begin{array}{l}\text { Private Health } \\
\text { Insurance }\end{array}$ & $\begin{array}{l}0.053 \\
(6.18)\end{array}$ & $\begin{array}{l}0.074 \\
(6.64)\end{array}$ \\
\hline $\begin{array}{l}\text { Public Health } \\
\text { Insurance } \\
\text { Income } 10 \text { - } \\
20,000\end{array}$ & $\begin{array}{c}-0.063 \\
(5.20) \\
-4.3 \mathrm{E}-4 \\
(0.03)\end{array}$ & $\begin{array}{c}-0.010 \\
(0.76) \\
0.025 \\
(1.44)\end{array}$ \\
\hline $\begin{array}{l}\text { Income } 20 \text { - } \\
30,000\end{array}$ & $\begin{array}{c}-0.002 \\
(1.73)\end{array}$ & $\begin{array}{l}0.034 \\
(2.21)\end{array}$ \\
\hline $\begin{array}{l}\text { Income } 30- \\
40,000\end{array}$ & $\begin{array}{l}0.003 \\
(0.26)\end{array}$ & $\begin{array}{l}0.070 \\
(3.73)\end{array}$ \\
\hline $\begin{array}{l}\text { Income } 40- \\
50,000\end{array}$ & $\begin{array}{c}-0.012 \\
(0.75)\end{array}$ & $\begin{array}{l}0.084 \\
(3.66)\end{array}$ \\
\hline $\begin{array}{l}\text { Income } \\
50,000+\end{array}$ & $\begin{array}{c}-0.014 \\
(0.92)\end{array}$ & $\begin{array}{l}0.125 \\
(6.39)\end{array}$ \\
\hline Family Size & $\begin{array}{l}0.015 \\
(3.53)\end{array}$ & $\begin{array}{l}0.001 \\
(0.36)\end{array}$ \\
\hline Single & $\begin{array}{l}0.051 \\
(5.37)\end{array}$ & $\begin{array}{r}-0.076 \\
(5.57)\end{array}$ \\
\hline $\begin{array}{l}\text { Divorced/ } \\
\text { Separated }\end{array}$ & $\begin{array}{c}-0.068 \\
(7.83)\end{array}$ & $\begin{array}{r}-0.087 \\
(7.20)\end{array}$ \\
\hline Widowed & $\begin{array}{c}0.029 \\
(1.80)\end{array}$ & $\begin{array}{l}-0.074 \\
(3.90)\end{array}$ \\
\hline
\end{tabular}

\footnotetext{
${ }^{\mathrm{a}}$ Marginal effects computed at sample means. Asymptotic z-statistics in parentheses. Robust, cluster-corrected standard errors.

${ }^{\mathrm{b}} \mathrm{N}=24,646$ (short form), 23,913 (long form).

${ }^{\mathrm{c}}$ Short form models include controls for age, race, and gender.

${ }^{\mathrm{d}}$ Long form models include short form variables, plus conrols for private and/or public insurance coverage, seat belt use, body mass, education, income, region, marital status, and family size.
} 
Table 15

\section{Cigarette Tax Coefficients $^{\mathrm{a}}$}

Smoking Status Models x Age Group

1991 \& 1993 National Health Interview Surveys ${ }^{b}$

\begin{tabular}{|c|c|c|c|c|}
\hline \multirow{2}{*}{$\begin{array}{l}\text { Variable } \\
\text { (N=Never; } \\
\text { Ever) }\end{array}$} & \multicolumn{2}{|c|}{ Never Smoked } & \multicolumn{2}{|c|}{\begin{tabular}{l|l|l|} 
Former Smoker & Ever Smoked \\
\end{tabular}} \\
\hline & Short Form ${ }^{\mathrm{c}}$ & Long Form & Short Form $^{c}$ & Long Form ${ }^{d}$ \\
\hline $\begin{array}{l}\text { Age } 18-21 \\
(\mathrm{~N}=3776 ; 1086)\end{array}$ & $\begin{array}{l}0.102 \\
(1.00)\end{array}$ & $\begin{array}{l}0.177 \\
(1.44)\end{array}$ & $\begin{array}{l}0.078 \\
(0.50)\end{array}$ & $\begin{array}{c}0.053 \\
(0.075)\end{array}$ \\
\hline $\begin{array}{l}\text { Age } 22-25 \\
(\mathrm{~N}=4518 ; 1659)\end{array}$ & $\begin{array}{l}0.108 \\
(1.01)\end{array}$ & $\begin{array}{l}0.252 \\
(3.21)\end{array}$ & $\begin{array}{l}0.233 \\
(2.31)\end{array}$ & $\begin{array}{l}0.239 \\
(1.70)\end{array}$ \\
\hline $\begin{array}{l}\text { Age } 26-30 \\
(\mathrm{~N}=7017 ; 3040)\end{array}$ & $\begin{array}{l}0.262 \\
(2.72)\end{array}$ & $\begin{array}{l}0.086 \\
(0.71)\end{array}$ & $\begin{array}{l}0.304 \\
(2.56)\end{array}$ & $\begin{array}{l}0.208 \\
(2.07)\end{array}$ \\
\hline $\begin{array}{l}\text { Age } 31-35 \\
(\mathrm{~N}=7749 ; 3906)\end{array}$ & $\begin{array}{l}0.246 \\
(2.65)\end{array}$ & $\begin{array}{l}0.157 \\
(1.85)\end{array}$ & $\begin{array}{l}0.245 \\
(1.90)\end{array}$ & $\begin{array}{l}-0.004 \\
(0.04)\end{array}$ \\
\hline $\begin{array}{l}\text { Age 36-45 } \\
(\mathrm{N}=13,083 ; 699 \\
8)\end{array}$ & $\begin{array}{l}0.013 \\
(0.15)\end{array}$ & $\begin{array}{l}-0.40 \\
(0.37)\end{array}$ & $\begin{array}{l}0.118 \\
(1.25)\end{array}$ & $\begin{array}{l}-0.003 \\
(0.03)\end{array}$ \\
\hline $\begin{array}{l}\text { Age } 46-55 \\
(\mathrm{~N}=8427 ; 5097)\end{array}$ & $\begin{array}{c}0.074 \\
(0.092)\end{array}$ & $\begin{array}{l}0.007 \\
(0.05)\end{array}$ & $\begin{array}{l}0.212 \\
(2.07)\end{array}$ & $\begin{array}{l}-0.161 \\
(1.81)\end{array}$ \\
\hline $\begin{array}{l}\text { Age 56-65 } \\
(\mathrm{N}=7342 ; 4415)\end{array}$ & $\begin{array}{l}-0.032 \\
(0.036)\end{array}$ & $\begin{array}{l}-0.009 \\
(0.08)\end{array}$ & $\begin{array}{l}0.231 \\
(2.08)\end{array}$ & $\begin{array}{l}-0.125 \\
(0.89)\end{array}$ \\
\hline
\end{tabular}

${ }^{\mathbf{a}}$ Marginal effects computed at sample means. Asymptotic z-statistics in parentheses.

Robust, cluster-corrected standard errors.

${ }^{\mathrm{b}} \mathrm{N}=24,646$ (short form), 23,913 (long form).

${ }^{\mathrm{c}}$ Short form models include controls for age, race, and gender.

${ }^{\mathrm{d}}$ Long form models include short form variables, plus controls for private and/or public insurance coverage, seat belt use, body mass, education, income, region, marital status, and family size. 
Table 16

Health Indicator, and Self-Reported Health Status,

By Smoking Status, 1991 NHIS

\begin{tabular}{|c|c|c|c|c|c|c|}
\hline Variable & $\begin{array}{l}\text { Never } \\
\text { Smoker }\end{array}$ & $\begin{array}{l}\text { Current } \\
\text { Smoker }\end{array}$ & $\begin{array}{l}\text { Quit }<1 \\
\text { Year }\end{array}$ & $\begin{array}{l}\text { Quit } 1 \text { to } \\
4 \text { Years }\end{array}$ & $\begin{array}{l}\text { Quit } 5 \text { to } \\
9 \text { Years }\end{array}$ & $\begin{array}{l}\text { Quit }>10 \\
\text { Years }\end{array}$ \\
\hline $\begin{array}{l}\text { Lost Work } \\
\text { Days }\end{array}$ & $\begin{array}{c}0.118 \\
(0.882)\end{array}$ & $\begin{array}{c}0.181 \\
(1.164)\end{array}$ & $\begin{array}{c}0.282 \\
(1.508)\end{array}$ & $\begin{array}{c}0.127 \\
(0.932)\end{array}$ & $\begin{array}{c}0.132 \\
(0.971)\end{array}$ & $\begin{array}{c}0.125 \\
(0.964)\end{array}$ \\
\hline $\begin{array}{l}\text { Hospital } \\
\text { Episodes }\end{array}$ & $\begin{array}{c}0.081 \\
(0.357)\end{array}$ & $\begin{array}{c}0.101 \\
(0.410)\end{array}$ & $\begin{array}{c}0.241 \\
(0.655)\end{array}$ & $\begin{array}{c}0.140 \\
(0.487)\end{array}$ & $\begin{array}{c}0.136 \\
(0.570)\end{array}$ & $\begin{array}{c}0.149 \\
(0.505)\end{array}$ \\
\hline Hospital Days & $\begin{array}{c}0.508 \\
(3.588)\end{array}$ & $\begin{array}{c}0.622 \\
(4.362)\end{array}$ & $\begin{array}{c}2.545 \\
(12.850)\end{array}$ & $\begin{array}{c}0.967 \\
(6.324)\end{array}$ & $\begin{array}{c}0.833 \\
(4.368)\end{array}$ & $\begin{array}{c}0.941 \\
(4.348)\end{array}$ \\
\hline Doctor Visits & $\begin{array}{c}4.112 \\
(10.135)\end{array}$ & $\begin{array}{c}4.490 \\
(13.440)\end{array}$ & $\begin{array}{c}6.786 \\
(24.980)\end{array}$ & $\begin{array}{c}5.712 \\
(18.291)\end{array}$ & $\begin{array}{c}5.073 \\
(12.778)\end{array}$ & $\begin{array}{c}5.100 \\
(11.304)\end{array}$ \\
\hline $\begin{array}{l}\text { Excellent } \\
\text { Health }\end{array}$ & $\begin{array}{c}0.372 \\
(0.483)\end{array}$ & $\begin{array}{c}0.284 \\
(0.451)\end{array}$ & $\begin{array}{c}0.339 \\
(0.473)\end{array}$ & $\begin{array}{c}0.325 \\
(0.468)\end{array}$ & $\begin{array}{c}0.323 \\
(0.468)\end{array}$ & $\begin{array}{c}0.304 \\
(0.460)\end{array}$ \\
\hline $\begin{array}{l}\text { Very Good } \\
\text { Health }\end{array}$ & $\begin{array}{c}0.295 \\
(0.456)\end{array}$ & $\begin{array}{c}0.289 \\
(0.453)\end{array}$ & $\begin{array}{c}0.295 \\
(0.456)\end{array}$ & $\begin{array}{c}0.290 \\
(0.454)\end{array}$ & $\begin{array}{c}0.283 \\
(0.451)\end{array}$ & $\begin{array}{c}0.281 \\
(0.449)\end{array}$ \\
\hline Good Health & $\begin{array}{c}0.235 \\
(0.425)\end{array}$ & $\begin{array}{c}0.280 \\
(0.449)\end{array}$ & $\begin{array}{c}0.227 \\
(0.419)\end{array}$ & $\begin{array}{c}0.247 \\
(0.431)\end{array}$ & $\begin{array}{c}0.238 \\
(0.426)\end{array}$ & $\begin{array}{c}0.260 \\
(0.439)\end{array}$ \\
\hline Fair Health & $\begin{array}{c}0.073 \\
(0.260)\end{array}$ & $\begin{array}{c}0.104 \\
(0.306)\end{array}$ & $\begin{array}{c}0.094 \\
(0.292)\end{array}$ & $\begin{array}{c}0.096 \\
(0.294)\end{array}$ & $\begin{array}{c}0.106 \\
(0.308)\end{array}$ & $\begin{array}{c}0.110 \\
(0.313)\end{array}$ \\
\hline Poor Health & $\begin{array}{c}0.024 \\
(0.152)\end{array}$ & $\begin{array}{c}0.042 \\
(0.200)\end{array}$ & $\begin{array}{c}0.045 \\
(0.207)\end{array}$ & $\begin{array}{c}0.043 \\
(0.202)\end{array}$ & $\begin{array}{c}0.049 \\
(0.049)\end{array}$ & $\begin{array}{c}0.045 \\
(0.207)\end{array}$ \\
\hline
\end{tabular}

\footnotetext{
${ }^{\mathrm{a}}$ Weighted means, not adjusted for age and sex
} 
Table 17

Smoking and Health Care Utilization

Negative Binomial Regression Estimates ${ }^{\text {a }}$

Worker Sample ${ }^{b}$

\begin{tabular}{|c|c|c|c|c|}
\hline Variable & $\begin{array}{l}\text { Hospital } \\
\text { Episodes } \\
\end{array}$ & $\begin{array}{l}\text { Hospital } \\
\text { Days }\end{array}$ & $\begin{array}{l}\text { Doctor } \\
\text { Visits } \\
\end{array}$ & $\begin{array}{l}\text { Lost } \\
\text { Workdays }\end{array}$ \\
\hline \multicolumn{5}{|l|}{$\begin{array}{l}\text { Short Form } \\
\text { Models }\end{array}$} \\
\hline Current Smoker & $\begin{array}{c}1.290 \\
(3.612)\end{array}$ & $\begin{array}{c}1.696 \\
(4.611)\end{array}$ & $\begin{array}{c}1.112 \\
(5.027)\end{array}$ & $\begin{array}{c}1.566 \\
(5.229)\end{array}$ \\
\hline \multicolumn{5}{|l|}{$\begin{array}{l}\text { Former Smoker } \\
\text { (years quit) }\end{array}$} \\
\hline$<1$ & $\begin{array}{c}2.467 \\
(5.515)\end{array}$ & $\begin{array}{c}3.170 \\
(4.012)\end{array}$ & $\begin{array}{c}1.350 \\
(4.930)\end{array}$ & $\begin{array}{c}2.263 \\
(3.339)\end{array}$ \\
\hline $1-4$ & $\begin{array}{c}1.231 \\
(1.306)\end{array}$ & $\begin{array}{c}1.044 \\
(0.161)\end{array}$ & $\begin{array}{c}1.426 \\
(7.253)\end{array}$ & $\begin{array}{c}1.077 \\
(0.368)\end{array}$ \\
\hline $5-9$ & $\begin{array}{c}1.273 \\
(1.661)\end{array}$ & $\begin{array}{c}1.540 \\
(1.745)\end{array}$ & $\begin{array}{c}1.220 \\
(4.358)\end{array}$ & $\begin{array}{c}1.101 \\
(0.514)\end{array}$ \\
\hline $10+$ & $\begin{array}{c}1.128 \\
(1.114)\end{array}$ & $\begin{array}{c}1.012 \\
(0.068)\end{array}$ & $\begin{array}{c}1.224 \\
(6.020)\end{array}$ & $\begin{array}{c}1.129 \\
(0.886)\end{array}$ \\
\hline \multicolumn{5}{|l|}{$\begin{array}{l}\text { Long Form } \\
\text { Models }^{d}\end{array}$} \\
\hline Current Smoker & $\begin{array}{c}1.220 \\
(2.696)\end{array}$ & $\begin{array}{c}1.374 \\
(2.639)\end{array}$ & $\begin{array}{c}1.172 \\
(7.042))\end{array}$ & $\begin{array}{c}1.404 \\
(3.751)\end{array}$ \\
\hline \multicolumn{5}{|l|}{$\begin{array}{l}\text { Former Smoker } \\
\text { (years quit) }\end{array}$} \\
\hline$<1$ & $\begin{array}{c}2.398 \\
(5.354)\end{array}$ & $\begin{array}{c}3.097 \\
(3.444)\end{array}$ & $\begin{array}{c}1.373 \\
(5.175)\end{array}$ & $\begin{array}{c}2.144 \\
(3.098)\end{array}$ \\
\hline $1-4$ & $\begin{array}{c}1.201 \\
(1.148)\end{array}$ & $\begin{array}{c}1.071 \\
(0.253)\end{array}$ & $\begin{array}{c}1.409 \\
(6.904)\end{array}$ & $\begin{array}{c}1.020 \\
(0.094)\end{array}$ \\
\hline $5-9$ & $\begin{array}{c}1.193 \\
(1.191)\end{array}$ & $\begin{array}{c}1.248 \\
(0.887)\end{array}$ & $\begin{array}{c}1.184 \\
(3.648)\end{array}$ & $\begin{array}{c}1.031 \\
(0.159)\end{array}$ \\
\hline $10+$ & $\begin{array}{c}1.078 \\
(0.690)\end{array}$ & $\begin{array}{c}0.973 \\
(0.150)\end{array}$ & $\begin{array}{c}1.180 \\
(4.878)\end{array}$ & $\begin{array}{c}1.126 \\
(0.856)\end{array}$ \\
\hline
\end{tabular}

\footnotetext{
${ }^{a}$ Estimated coefficients from negative binomial regression models, reported as incidence rates, with asymptotic z-statistics in parentheses. Robust, cluster-corrected standard errors.
} 
${ }^{\mathrm{b}} \mathrm{N}=$ (short form); (long form).

${ }^{\mathrm{c}}$ Short form models include controls for age, race, and gender.

${ }^{\mathrm{d}}$ Long form models include short form variables, plus controls for private and/or public insurance coverage, seat belt use, body mass, education, income, region, marital status, and family size. 
Table 18

Smoking and Health Care Utilization

Negative Binomial Regression Estimates ${ }^{a}$

Nonworker Sample

\begin{tabular}{lllll}
\hline Variable & Hospital & Hospital & Doctor & Lost \\
& Episodes & Days & Visits & Workdays \\
\hline
\end{tabular}

Short Form

Models

Current Smoker

$\begin{array}{ccc}1.537 & 1.497 & 1.201 \\ (5.026) & (2.897) & (5.222)\end{array}$

NA

Former Smoker

(years quit)

$\begin{array}{lccc}<1 & 2.939 & 4.248 & 2.085 \\ & (5.532) & (3.839) & (7.678) \\ 1-4 & & & \\ & 2.274 & 3.106 & 1.480 \\ 5-9 & (4.767) & (3.609) & (4.902) \\ & & & \\ & 1.522 & 1.197 & 1.224 \\ 10+ & (2.305) & (0.556) & (2.511) \\ & & & \\ & 1.296 & 1.022 & 1.179 \\ & (1.918) & (0.096) & (2.822)\end{array}$

Long Form

Models $^{\mathrm{d}}$

Current Smoker

1.257

1.282

NA

(2.525)

(1.643)

1.125

(3.164)

Former Smoker

(years quit)

$\begin{array}{cccc}<1 & 2.850 & 4.198 & 1.840 \\ & (5.377) & (3.775) & (6.420) \\ 1-4 & 1.942 & 2.472 & 1.548 \\ & (3.847) & (2.784) & (5.383) \\ 5-9 & 1.417 & 1.209 & 1.254 \\ & (1.905) & (0.578) & (2.831) \\ 10+ & & & \\ & 1.231 & 1.129 & 1.127 \\ & (1.522) & (0.522) & (2.073)\end{array}$


${ }^{a}$ Estimated coefficients from negative binomial regression models, reported as incidence rates, with asymptotic $\mathrm{z}$-statistics in parentheses. Robust, cluster-corrected standard errors.

${ }^{\mathrm{b}} \mathrm{N}=9,521$ (short form); 9,165 (long form).

${ }^{c}$ Short form models include controls for age, race, and gender.

${ }^{\mathrm{d}}$ Long form models include short form variables, plus controls for private and/or public insurance coverage, seat belt use, body mass, education, income, region, marital status, and family size. 
Table 19

Smoking and Health Care Utilization

Negative Binomial Reduced Form Regression Estimates ${ }^{\text {a }}$

Age-Specific Estimates of Tax Effects

Worker Sample ${ }^{\mathrm{b}}$

\begin{tabular}{lllll}
\hline Variable & Hospital & Hospital & Doctor & Lost \\
& Episodes & Days & Visits & Workdays \\
\hline
\end{tabular}

Short Form
Models

Age 18-21

1.006

1.024

0.999

0.992

(0.708)

$(0.647)$

(0.433)

(0.561)

Age 22-25

1.004

1.011

1.007

1.007

(0.448)

(0.842)

(3.146)

(0.783)

Age 26-30

0.994

0.997

1.007

0.999

(0.865)

(0.245)

(3.797)

(0.180)

Age 31-35

0.982

0.991

1.306

0.991

(2.782)

(0.950)

(2.842)

(0.180)

Age 36-45

0.992
$(1.687)$

0.996

1.002

(1.392)

1.001

(0.498)

(0.085)

Age 46-55

0.984

0.979

1.003

0.983

(3.292)

(2.728)

(1.935)

(2.025)

Age 56-65

0.997

1.003

1.004

1.004

(0.604)

(0.377)

(1.977)

(0.353)

Pooled Sample

$\begin{array}{cc}0.992 & 0.997 \\ (3.685) & (0.824)\end{array}$

1.004

0.996

(3.685)

(5.428)

(1.159)

\footnotetext{
${ }^{a}$ Estimated coefficients from negative binomial regression models, reported as incidence rates, with asymptotic z-statistics on parentheses, Robust, cluster-corrected standard errors.

${ }^{\mathrm{b}} \mathrm{N}=24,646$ (short form), 23,913 (long form).

${ }^{\mathrm{c}}$ Short form models include controls for age, race, and gender.

${ }^{\mathrm{d}}$ Long form models include short form variables, plus controls for private and/or public insurance coverage, seat belt use, body mass, education, income, region, marital status, and family size.
} 


\begin{tabular}{lcccc}
$\begin{array}{l}\text { Long Form } \\
\text { Models }\end{array}$ & & & \\
& & & \\
Age 18-21 & 1.001 & 1.004 & 0.999 & 0.983 \\
& $(0.056)$ & $(0.232)$ & $(0.048)$ & $(0.937)$ \\
Age 22-25 & 1.009 & 1.012 & 1.003 & 0.984 \\
& $(0.834)$ & $(0.624)$ & $(0.808)$ & $(1.080)$ \\
& & & & \\
Age 26-30 & 0.997 & 1.009 & 1.007 & 1.006 \\
& $(0.358)$ & $(0.585)$ & $(2.722)$ & $(0.478)$ \\
Age 31-35 & 0.986 & 1.003 & 0.996 & 1.001 \\
& $(1.585)$ & $(0.209)$ & $(0.129)$ & $(0.073)$ \\
Age 36-45 & 0.995 & 0.985 & 0.999 & 1.005 \\
& $(0.838)$ & $(1.339)$ & $(0.695)$ & $(0.461)$ \\
Age 46-55 & & & & \\
& 0.990 & 0.980 & 0.997 & 0.982 \\
Age 56-65 & $(1.434)$ & $(1.685)$ & $(1.176)$ & $(1.388)$ \\
& & & & \\
& 0.997 & 0.999 & 0.997 & 1.012 \\
& $(0.505)$ & $(1.064)$ & $(1.292)$ & $(0.653)$ \\
& 0.995 & 1.001 & 1.000 & 1.002 \\
& $(1.697)$ & $(0.214)$ & $(0.475)$ & $(0.445)$ \\
\hline
\end{tabular}

\footnotetext{
${ }^{a}$ Estimated coefficients, reported as incidence rates, with asymptotic z-statistics in parentheses. Robust, cluster-corrected standard errors.

${ }^{b} \mathrm{~N}=24,646$ (short form), 23, 913, (long form).

'Short form models include controls for age, race, and gender.

${ }^{\mathrm{d}}$ Long form models include short form variables, plus controls for private and/or public insurance coverage, seat belt use, body mass, education, income, region, marital status, and family size.
} 